\title{
The fission yeast SPB component Cut12 links bipolar spindle formation to mitotic control
}

\author{
Alan J. Bridge, Mary Morphew, ${ }^{1}$ Rachel Bartlett, ${ }^{2}$ and Iain M. Hagan ${ }^{3}$ \\ School of Biological Sciences, University of M anchester, Manchester, M 13 9PT UK; ${ }^{1}$ Department of M olecular, Cellular, \\ and Devel opmental Biology, U niversity of Colorado, Boulder, Colorado 80309-0347 USA; ${ }^{2}$ Imperial Cancer Research Fund \\ (ICRF), London, WC2A 3PX UK.
}

\begin{abstract}
During fission yeast mitosis, the duplicated spindle pole bodies (SPBs) nucleate microtubule arrays that interdigitate to form the mitotic spindle cut12.1 mutants form a monopolar mitotic spindle, chromosome segregation fails, and the mutant undergoes a lethal cytokinesis. The cut12 ${ }^{+}$gene encodes a novel 62-kD protein with two predicted coiled coil regions, and one consensus phosphorylation site for $134^{\text {cdc2 }}$ and two for MAP kinase. Cut12 is localized to the SPB throughout the cell cycle, predominantly around the inner face of the interphase SPB, adjacent to the nucleus. cut $12^{+}$is allelic to stf1 $1^{+}$; stf1.1 is a gein-of-function mutation bypassing the requirement for the Cdc25 tyrosine phosphatase, which normally dephosphorylates and activates the $134^{\text {cdc2 }} /$ cyclin B kinase to promote the onset of mitosis. Expressing a cut12 ${ }^{+}$CDNA carrying the stf1.1 mutation also suppressed cdc25.22. The spindle defect in cut12.1 is exacerbated by the cdc25.22 mutation, and stf1.1 cells formed defective spindles in a cdc25.22 background at high temperatures. We propose that Cut12 may be a regulator or substrate of the $p 34^{\text {cdc2 }}$ mitotic kinase.
\end{abstract}

[Key Words: Mitosis; SPB; cut12; cdc25; MPF; S. pombe]

Received August 29, 1997; revised version accepted February 4, 1998.

Microtubule organizing centers (MTOCs) play a key role in nucl eating microtubule assembly and organizing existing microtubul es during the formation of a bi pol ar mitotic spindle (Kalt and Schliwa 1993). The onset of mitosis is preceded by MTOC duplication and maturation (Balczon 1996). Mitotic onset is accompanied by the nucleation of an increased number of highly dynamic microtubules from the MTOCs (Kirschner and Mitchison 1986; Hyman and Karsenti 1996). The increase in both the number and dynamics of microtubules nucleated by the MTOC is ultimately controlled by mitosis promoting factor (M PF), a dimer consisting of the p34 ${ }^{\text {cdc2 }}$ kinase subunit and a mitotic B-type cycl in (N urse 1990). A fraction of cellular MPF has been localized to the MTOCs of organi sms as diverse as yeast and man (Alfa et al. 1990; Bailly et al. 1989, 1992; Pines and Hunter 1991; Buendi a et al. 1992; M al donado-Codina and Glover 1992; Ohta et al . 1993; Pockwinse et al. 1997). The M PF component of Xenopus egg extracts is capable of indirectly activating the spindle microtubule nucleation capacity of the interphase spindle pole body (SPB) of permeabilized fission yeast cells (M asuda et al. 1992), and induces the increase in microtubule dynamics in vitro which is characteristic of the mitotic state (Belmont et al. 1990; Verde et al. 1990, 1992). The mitotic p34 ${ }^{\text {cdc2 }}$ kinase may

${ }^{3}$ Corresponding author.

E-MAIL lain.Hagen@man.ac.uk; FAX 441612755082. promote bipolar spindle formation by directly phosphoryl ating and activating components of the spindle apparatus such as mitotic microtubule based motor proteins (Blangy et al . 1995). Alternately, p34 cdc2 may phosphoryl ate and activate other kinases required for spindle formation, such as the NIM A (never in mitosis) kinase in Aspergillus nidulans (Ye et al. 1995). NIM A activity is essential for progression into mitosis even in the presence of active $\mathrm{p} 34^{\mathrm{cdc2}}$ / cyclin B, and N IM A is phosphorylated and stimulated by $\mathrm{p} 34^{\mathrm{cdc}}$ dependent phosphorylation in vitro (Ye et al. 1995, 1996). Thus, NIM A may act downstream of p34 ${ }^{\mathrm{cdc} 2}$ to promote spindle formation at the onset of mitosis. In addition to p34 cdc2 and the NIMA kinase, a family of conserved kinases termed the Polo-like kinases (PIks) play an essential role in bipolar spindle formation in a range of different eukaryotes (Glover et al. 1996). A human PIk is required for MTOC maturation (Lane and Nigg 1996) and a Xenopus PIK can phosphorylate and activate the MPF activator Cdc25 (Kumagai and Dunphy 1996). Thus, the PIks may act to promote the activation of $\mathrm{p} 34^{\mathrm{cdc}}$ kinase and spindl e formation upon maturation of the duplicated MTOCs (Lane and N igg 1996).

The rapid changes in the organization of the microtubule cytoskel eton in Schizosaccharomyces pombe that accompany entry into mitosis are similar to those seen in higher eukaryotes and make the fission yeast an excellent model system for the study of mitotic spindle 
formation (Tanaka and Kanbe 1986; Hagan and Hyams 1988; Ding et al. 1993; Hagan and Y anagida 1997; Saito et al. 1997). Like its higher eukaryotic equivalent, the centrosome, the fission yeast SPB is excluded from the nucleus during interphase (Ding et al. 1997). In prophase, the duplicated SPBs gain access to the chromosomes through a restricted opening of the nuclear envelope and begin to nucl eate spindle microtubules (Ding et al . 1997). At the onset of anaphase, the spindle microtubules decrease in number as they increase in length, and the opening in the nuclear envel ope adjacent to the SPB begins to close (Ding et al. 1993, 1997). After anaphase, spindle microtubules disassemble, the SPB returns to the cytoplasm, and cytoplasmic microtubule arrays are reestablished from MTOCs at the cell equator (Hagan and Hyams 1988; Horio et al. 1991; Pichova et al. 1995) and from the outer face of the SPB (Hagan and Yanagida 1997).

Here we report the characterization of the cut $12^{+}$ spindle formation gene and its product. In the temperature sensitive cut12.1 mutant only one of the two structures recogni zed by SPB specific antibodies nucl eates $\mathrm{mi}$ crotubules, leading to monopolar spindle formation and asymmetric chromosome segregation. The cut $12^{+}$gene encodes a novel $62-\mathrm{kD}$ protein that is essential for bipolar spindle formation and localizes to the SPB throughout the cell cycle. The cut $12^{+}$locus is allelic to a previously identified mutation termed stf1.1 for suppressor of cdc twenty-five (Hudson et al. 1990). stfl.1 is a semidominant mutation that bypasses the requirement for Cdc25, a normally essential tyrosine phosphatase that removes an inhibitory phosphate from p34 ${ }^{\text {cdc2 }}$ (Hudson et al . 1990). We di scuss the implications of these findings for spindle formation and cell cycle control.

\section{Results}

Isolation and characterization of the cut12.1 mutant

A screen for temperature-sensitive mutants that increase in ploidy at the restrictive temperature has identified several mitotic mutants that undergo asymmetric chromosome segregation such as the temperature-sensitive mutant cut12.1 (Broek et al. 1991; Hayles et al. 1994; A.M. Poziemba, A. Woollard, R.A. Craven, P. N urse, and I. Hagan, unpubl.). To determine the precise nature of the defect in cut12.1 an asynchronous culture of cut12.1 was shifted from $25^{\circ} \mathrm{C}$ to the restrictive temperature of $36^{\circ} \mathrm{C}$ and stained with antibodies against the SPB component Sadl (Hagan and Yanagida 1995) and tubulin (Woods et al. 1989). At $36^{\circ} \mathrm{C}$, the cut 12.1 mutant entered mitosis but formed defective mitotic spindles. Although two Sad1 foci were often visible, only one of the two presumptive SPBs in each cell retained all the functions necessary to nucleate mi crotubules (Fig. 1, cells 1 and 2). The inactive Sad1 focus stained less intensely, and in extreme cases, microtubules arose from a point devoid of Sad1 (Fig. 1, cell 2). The differential staining of the two Sad1 foci is illustrated most clearly in a merged false color immunofluorescence image (Fig. 1g). Hence, the spindles formed in the cut12.1 mutant were monopolar, and the condensed chromatin remained in a single unsegregated mass. In spite of this defect, cells proceeded through cytokinesis, a so-called cut division, generating aneuploid (Fig. 1, cell 3) and diploid cells (Fig. 1, cell 4). As the Sad1 foci were inactive, they were randomly segregated by the central cut division.

To examine the phenotype of the cut12.1 mutant in more detail, an early $G_{2}$ population of cut 12.1 cells was isolated at $25^{\circ} \mathrm{C}$ by lactose gradient centrifugation, and an al iquot was shifted to $36^{\circ} \mathrm{C}$ before samples were taken every $20 \mathrm{~min}$ for $6 \mathrm{hr}$ for immunofluorescence. The population of cells entered a synchronous mitosis at both permissive and restrictive temperature, but formed monopolar mitotic spindles at the restrictive temperature and underwent cut divisions. The relative timing of appearance of these phenotypes is shown in Figure $1 \mathrm{~h}$. The loss of viability of the cut12.1 mutant on shift to the restrictive temperature preceded the appearance of defective spindles and cut divisions, indicating that the defect in cut12.1 is not reversible or that the Cut12 protein is required in some process prior to spindle formation.

\section{Cloning and sequence analysis of the cut $12^{+}$gene}

The construction of a heterozygous cut $12^{+} /$cut12.1 diploid showed that cut12.1 is a recessive mutation (data not shown). The cut $12^{+}$gene was therefore cloned by complementation of the temperature-sensitive defect (Fig. 2a). The cut $12^{+}$gene encoded a 548 amino acid protein of $62 \mathrm{kD}$, with no overall homology to known proteins (Fig. 2b). The protein was found to be relatively hydrophilic and basic (pl of 9.4). Two regions (from amino acids 259 to 311 and 521 to 548) were predicted to form coiled coils according to the algorithm of Lupas et al. (1991). Amino acids 61-64 represented a potential phosphorylation target site for p34 ${ }^{\mathrm{cdc} 2}$ kinase (TPLK; N igg 1993), which also matched one of the two proposed M PM 2 kinase consensus sites (LTPLK; Westendorf et al. 1994). Two potential MAP kinase phosphorylation sites from amino acids 73-76 (LKTP) and 516-519 (LKSP) were also identified (Nigg 1993). The cut12.1 mutation is a single base change in the first nucleotide of codon 536 (CGA to TGA), which would be predicted to produce a truncated form of Cut12 lacking the carboxy-terminal 13 amino acids of the protein. As the minimum length required for the formation of a stable coiled coil is thought to be 28 amino acids (Lupas et al. 1991), the cut12.1 allele would be predicted to encode a protein lacking a coiled coil domain at its carboxyl terminus (Fig. 2c).

cut $12^{+}$gene del etion results in defective spindles and cut divisions

The formation of monopolar spindles in the cut12.1 mutant may be caused by the presence of sufficient Cut12 activity to allow activation of one of the two SPBs. Therefore, we examined the effect of a compl ete loss of Cut12 protein. One copy of the cut $12^{+}$gene was deleted in a dipl oid by replacing all of the coding region between the Ppu10l sites (Fig. 2b) with the ura $4^{+}$sequence of $\mathrm{S}$. 
The fission yeast SPB component Cut12 and MPF regulation
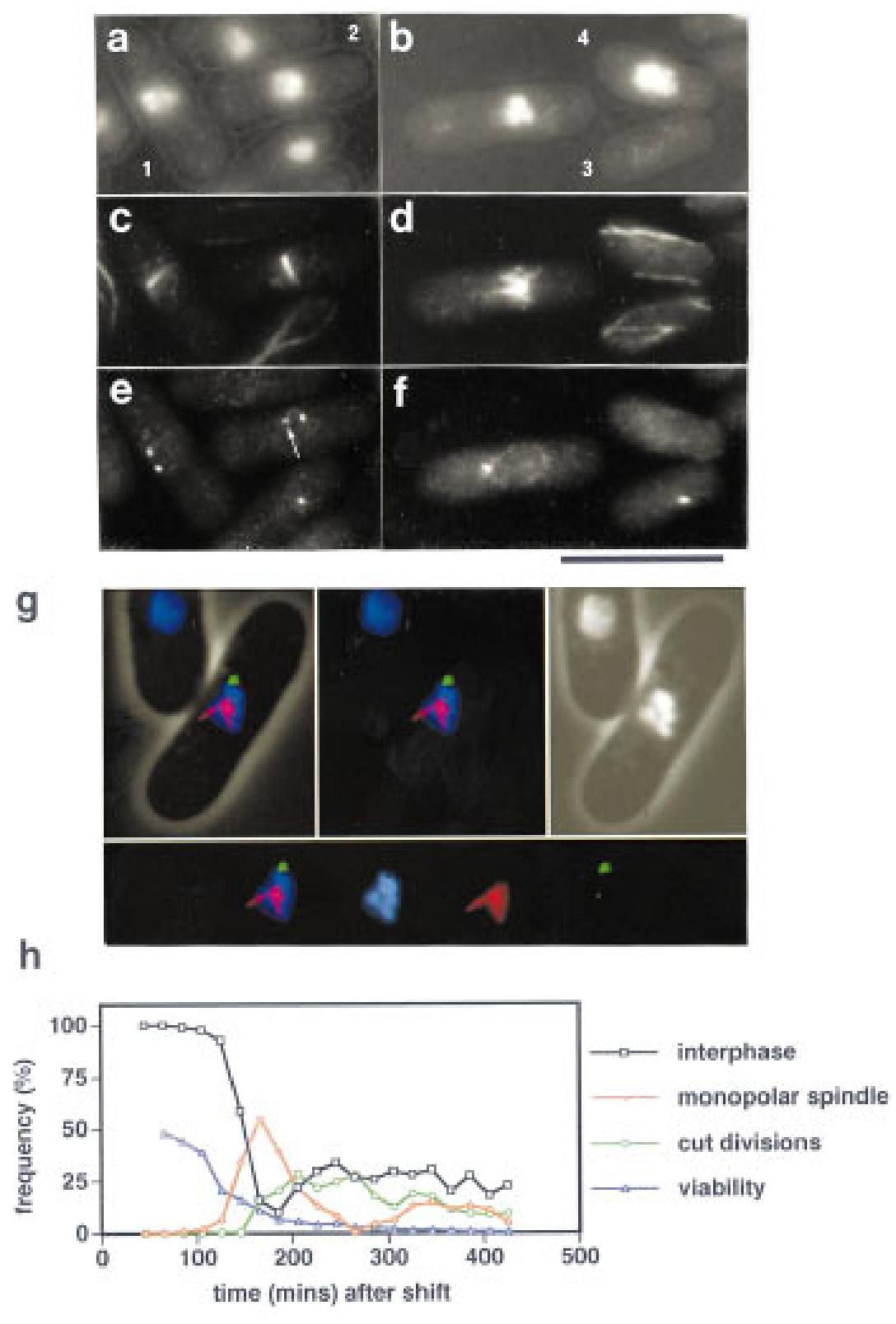

h

Figure 1. Monopolar mitotic spindle formation in the cut12.1 mutant. (a-f) Immunofluorescence analysis of an asynchronous culture of the cut12.1 mutant at restrictive temperature of $36^{\circ} \mathrm{C}$. $(a, b)$ phase/DAPI reveals cell outline and chromatin; (c,d) anti-tubulin staining; (e,f) antiSad1 staining. M onopolar mitotic spindles arose from one of the two foci of Sadl staining (cells 1 and 2). The microtubules normally arose from the less bright staining of the two Sad1 foci (indicated by an arrow in cell 2). Asymmetric segregation of the chromatin and Sad1 staining material led to the formation of aneuploid cells containing Sad1 (cell 3) and diploid cells that lack any detectable Sad1 staining (cell 4). Scale bar, $10 \mu \mathrm{m}$. (g) False color immunofluorescence image of a defective monopolar spindle in the cut12.1 mutant. Microtubules are shown in red, Sadl staining in green, and chromatin in blue. (Top left) M erged image reveals cell outline and spindle structures; (top middle) spindle structure alone; (top right) phase/DAPI staining; (bottom) individual spindle components. The microtubules arose from the less bright staining focus of Sad1 staining. (h) Time course of the loss of viability and the appearance of monopolar spindles and cut divisions in a population of the cut12.1 mutant grown at $25^{\circ} \mathrm{C}$, synchronized in early $\mathrm{G}_{2}$ by lactose gradient centrifugation, and then shifted to $36^{\circ} \mathrm{C}$. Note that the loss of viability precedes the appearance of defective spindles and cut divisions.

pombe, thereby removing all save the first 32 nucleotides of the gene and an additional 41 nucleotides downstream of the gene. Tetrad analysis demonstrated that the cut $12^{+}$gene is essential for viability at all temperatures tested from $20^{\circ} \mathrm{C}$ to $36^{\circ} \mathrm{C}$ (data not shown).

The cellular phenotypes resulting from deletion of cut $12^{+}$were examined by spore germination (Fig. 3a-c). Germinating $\mathrm{Ura}^{+}$spores entered mitosis and disassembled cytoplasmic microtubules and condensed their chromosomes. However, the cut12.d1 spores formed defective mitotic spindles in which microtubules were not associated with either of the two equally intense Sad1 foci. The position of the origin of spindle microtubules is indicated by an arrow in each of the three cells in Figure $3 c$, and clearly does not correl ate with the position of the Sad1 staining foci.
We al so examined the effect of a loss of Cut12 protein from a culture of the cut12.d1 haploid in which the cells were maintained in a viable state by the expression of the cut $12^{+}$CDNA from the pREP81 plasmid. The pREP81 plasmid carries an attenuated form of the thiamine repressible $\mathrm{nmt1}^{+}$promoter (Basi et al. 1993; Maundrell 1993). The repression of cut $12^{+}$transcription by the addition of $2 \mu \mathrm{m}$ thiamine resulted in the formation of defective monopolar spindles identical with those seen in the ts cut12.1 mutant, where the microtubules arose from the less intense of the two foci of Sadl staining (Fig. 3e,g,i). In control cultures expressing cut12, bi polar spindle formation was normal (Fig. 3d,f,h). Cells that formed defective spindles and underwent defective cut divisions were elongated relative to cells in which cut $12^{+}$expression was not repressed (mean cell length 
a
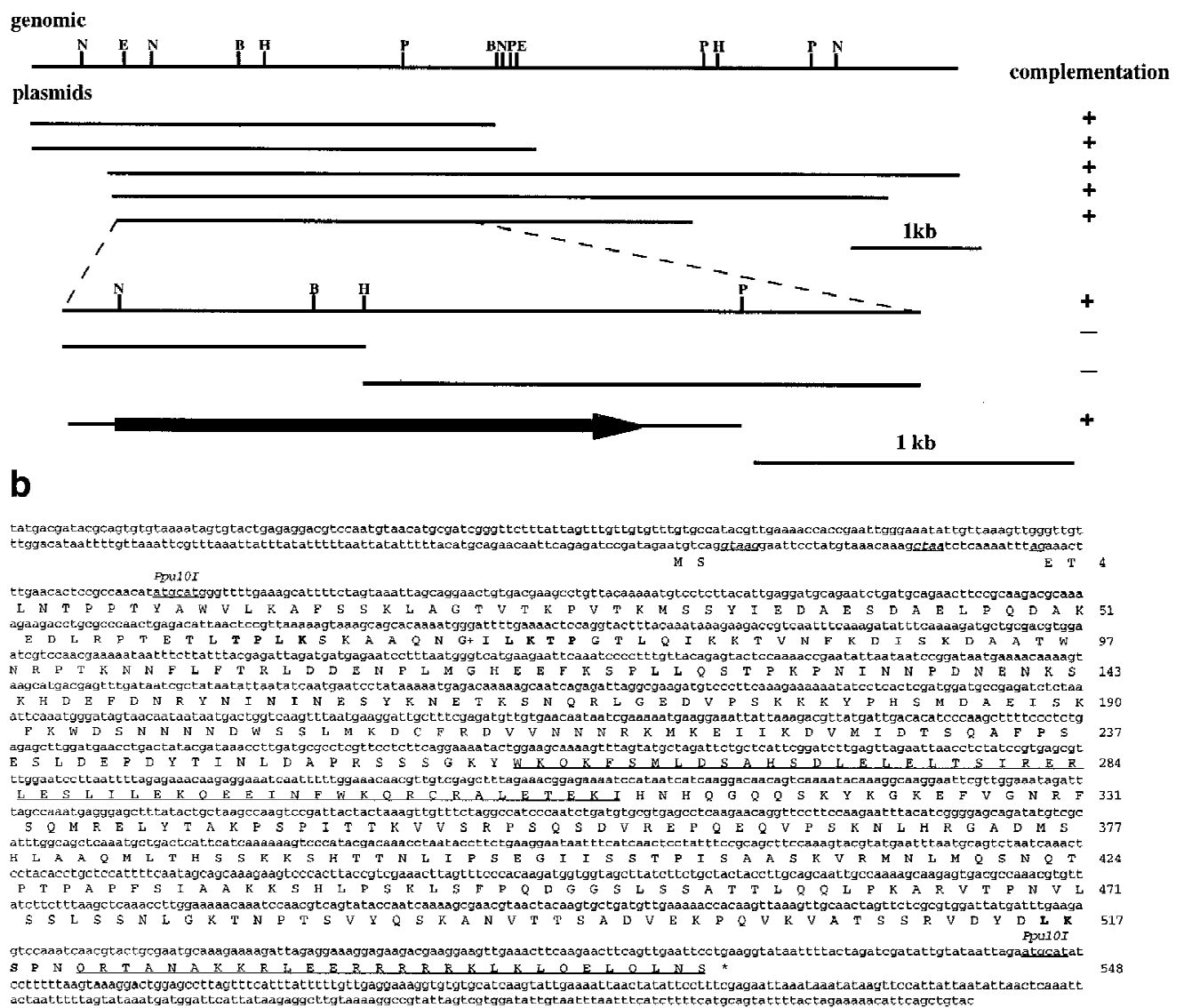

C
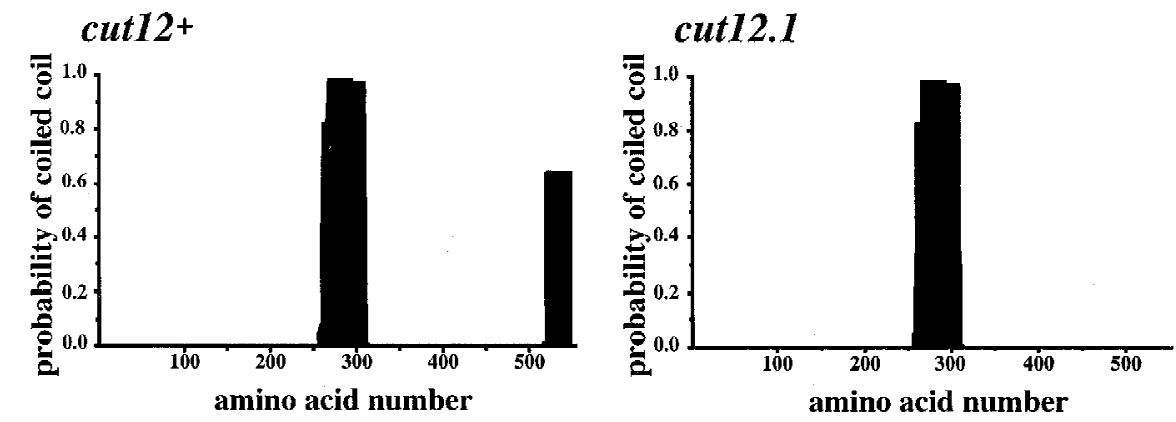

d

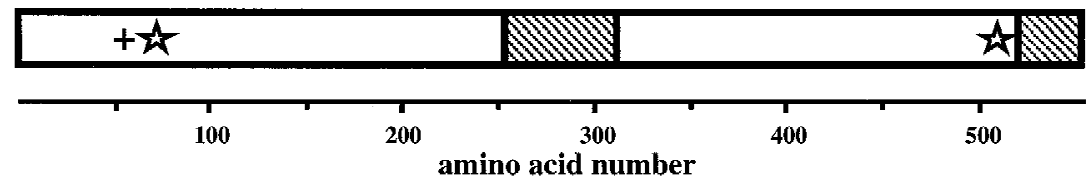

Figure 2. Cloning and molecular analysis of the cut $12^{+}$gene. (a) Restriction mapping and complementation analysis of the cut $12^{+}$ containing clones isolated by complementation of the cut12.1 mutant, and of subclones generated from the overlapping 2.8-kb region found in all cut12.1 complementing plasmids. (b) N ucl eotide and predicted amino acid sequence of the cut $12^{+}$gene. The cut $12^{+}$gene contained 2 exons of 7 and 1637 nucleotides, which together encode a predicted 548 amino acid protein of 62 kD. The two exons are separated by an intron of $42 \mathrm{bp}$; the consensus intron splice and branch sequences are shown underlined and in italics. The two regions of the Cut12 protein predicted to form coiled coils are underlined. The potential p34 ${ }^{\text {cdc2 }}$ and M AP kinase consensus sites are indicated in boldface type. $(\mathrm{G}+)$ The site of the stf1.1 mutation at glycine 71 . The GenBank accession no. for the cut $12^{+}$sequence is $Y 16837$. (c) Predicted coiled-coil regions in the Cut12 protein were determined by applying the al gorithm of Lupas et al . (1991) with a 28 amino acid window. (d) Schematic representation of the main features of the Cut12 protein. ( + ) p34 ${ }^{\text {cdc2 }}$ kinase consensus site; (star) MAP kinase consensus site; (hatched region) predicted region of coiled coil. 

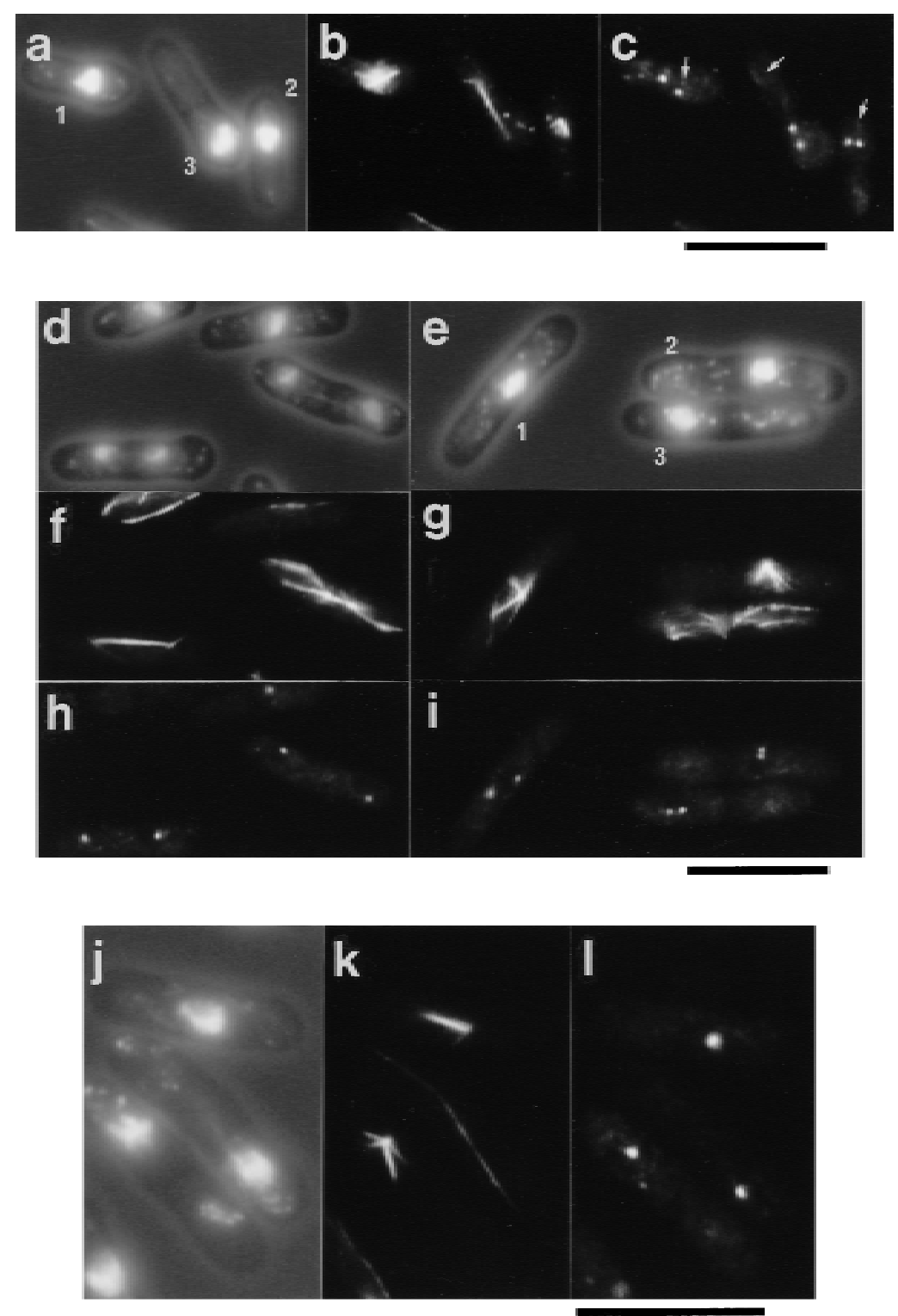

Figure3. Defective spindle formation in cells deleted for the cut $12^{+}$gene and cells overexpressing cut $12^{+}$. (a-c) Defective spindle formation and cut divisions in germinating cut12.d1 spores. Haploid spores prepared from a cut $12^{+} /$cut12.d1 diploid were germinated in minimal medium lacking uracil at $30^{\circ} \mathrm{C}$ and processed for immunofluorescence from 12 to $22 \mathrm{hr}$ after inoculation. Shown are three cells fixed $16 \mathrm{hr}$ after inoculation. (A) Phase/ DAPI reveals cell outline and chromatin; (B) antitubulin staining; (C) anti-Sadl staining. Germinating cut12.d1 spores appeared to contain two foci of Sad1 staining, although the microtubules arose from a position distal to both foci, indicated by an arrow for each of the three cells. Cells also underwent cut divisions (cell 3). Scal e bar, $10 \mu \mathrm{m}$. (d-i) Monopolar spindle formation and cut divisions following the switch off of plasmid borne cut $12^{+}$expression in cut12.d1 hapl oid cells. A culture of the cut12.d1 haploid maintained by the expression of a plasmid borne copy of the cut $12^{+}$ cDNA from the attenuated thiamine repressible $n m t 1^{+}$promoter was grown to log phase in minimal medium in the absence of thiamine at $30^{\circ} \mathrm{C}$. Aliquots were then inoculated into thiamine-free media to allow continued expression of cut $12^{+}$, and a second al iquot inoculated into medium containing thiamine to repress cut $12^{+}$expression. Samples were processed for immunofluorescence from 14 to $28 \mathrm{hr}$ later. $(\mathrm{d}, \mathrm{f}, \mathrm{h})$ cut $12^{+}$expressed; $(e, g, i)$ cut $12^{+}$repressed. (d,e) Phase/DAPI reveals cell outline and chromatin staining; $(f, g)$ anti-tubulin staining; $(h, i)$ anti-Sadl staining. Defective spindles formed in cells $\sim 14 \mathrm{hr}$ after repression of cut $12^{+}$. M onopolar spindles arose from only one of the two Sad1 foci (cell 1 and 2), similar to the ts cut12.1 mutant, and Cut divisions occurred (cell 3). Scale bar, $10 \mu \mathrm{m}$. (j-I) Immunofluorescence analysis of cells overexpressing cut $12^{+}$. Cells carrying the cut $12^{+}$cDNA linked to the wild-type nmt1 $1^{+}$promoter of the pREP1 plasmid were grown to mid log phase, the culture was divided in two, and cut $12^{+}$expression was derepressed in one half. Samples were taken every hour from 12 to $20 \mathrm{hr}$ following induction. Shown are cells in which cut $12^{+}$was derepressed for $16 \mathrm{hr}$. (j) Phase contrast/DAPI stain; (k) anti-tubulin staining; (I) anti-Sad1 staining. Cells overexpressing the cut $12^{+}$gene formed monopol ar spindles that seemed to arise from the single focus of Sadl staining visible within the cell. Cells in which cut $12^{+}$expression was repressed formed normal bipolar spindles (not shown). Scale bar, $10 \mu \mathrm{m}$.

$13.5 \mu \mathrm{m}$ S.E.M. $0.2 \mu \mathrm{m}$; and $12.4 \mu \mathrm{m}$, S.E.M. $0.1 \mu \mathrm{m}$, respectively; $n=50)$. Thus, the spindles formed in the absence of C ut12 protein are monopol ar and unable to support chromosome segregation, because of a defect in SPB duplication and/or activation or maturation.

\section{cut $12^{+}$overexpression perturbs bipolar spindle} formation

Bipolar spindle formation and cytokinesis were normal when cut $12^{+}$expression from the wild-type $n m t 1^{+}$promoter (Maundrell 1993) was repressed (data not shown), whereas on derepression, V-shaped spindles arising from the single focus of Sadl staining accumulated (Fig. 3j-I). A similar phenotype has been described for mutations in the kinesin-related gene cut7 ${ }^{+}(\mathrm{H}$ agan and $\mathrm{Y}$ anagida 1990) and the S. pombe Plk encoded by the $\mathrm{plol}^{+}$gene (Ohkura et al. 1995), and may result either from a defect in SPB duplication or from the inability of cells to resolvea parallel array of mi crotubules to a bi pol ar spindle. The cells that formed monopolar spindles were elongated relative to cells in which cut $12^{+}$expression was repressed (14.1 $\mu \mathrm{m}$, S.E.M. $0.2 \mu \mathrm{m}$, vs. $13.5 \mu \mathrm{m}$, S.E.M. 0.1 $\mu \mathrm{m}$, respectively; $\mathrm{n}=50$ ).

\section{Cut12 is an SPB component}

Several approaches were taken to local ize the Cut12 protein. Two polyclonal rabbit antisera were raised against amino acids 33 to 548 of the Cut12 protein fused to GST. 
Affinity-purified antibodies from these sera failed to recognize any bands in a protein extract prepared from germinating cut $12^{+}$del etion spores (Fig. $4 a$, lane 1 ) but recognized a single band of $\sim 62-k D$ by immunoblot of a wild-type S. pombe extract (Fig. 4a, lane 2). Overexpression of a cut $12^{+}$cDNA from the wild-type $n m t 1^{+}$promoter resulted in an increase in the intensity of this band (Fig. 4a, lane 3), whereas replacement of the wildtype cut $12^{+}$gene with a GFP-tagged version resulted in an increase in molecular mass to $\sim 90$ kD (Fig. 4a, lane 4). We conclude that p62 is the product of the cut $12^{+}$gene.

Exponentially growing wild-type cells were stained with anti-Cut12 and anti-tubulin antibodies. A single spot of anti-Cut12 staining was associated with the interphase chromatin, whereas in mitotic cells two discrete spots were seen at the mitotic spindle poles, consistent with Cut12 localization to the SPB (Fig. 4b). The intensity of these spots did not vary throughout the cell cycle.

A concern with immunolocalization data is that the specificity of antibodies in fixed samples may differ from that observed by Western bl ot analysis, so we used two additional methods to localize the Cut12 protein. In the first approach, the wild-type cut $12^{+}$gene was replaced with a version bearing the green fluorescent protein (GFP) CDNA of Aequorea victoria inserted at methionine 33 (Fig. 5a). The cells were viable, and formed normal spindles, although the frequency of cells with postanaphase arrays (PAAs) was approximately double that in wild-type controls type cells (not shown). One or two distinct dots of GFP fluorescence were seen per cell (Fig. $5 b-e)$. Staining with antibodies to the Sad1 protein confirmed that GFP and Sadl signals were coincident (Fig. $5 f-h)$. No variation in intensity of GFP signal was detected throughout the cell cycle.
Finally, the wild-type cut $12^{+}$gene was repl aced with a version of the gene bearing two copies of the $\mathrm{Pk}$ epitope tag (Hanke et al. 1992) at methionine 33 (S. pombe strain IH744). Staining of cells with anti-Pk and antiSad1 antibodies confirmed that the Pk and Sad1 signals were coincident throughout the cell cycle (data not shown). Depolymerization of microtubules by cold shock showed that localization of Cut12 to the SPB as judged by all three procedures was independent of microtubule integrity, indicating that Cut12 is a bona fide SPB component (data not shown).

\section{Cut12 protein localizes to the edge of the inner face of the SPB}

Cut12 protein was localized by simultaneous immunogold staining of S. pombe strain IH 744 with both monoclonal antibodies against the Pk epitope tag ( $5 \mathrm{~nm}$ gold) and polyclonal anti-Cut12 antibodies (10 nm gold). Both probes localized specifically to the periphery of the face of the cytoplasmic body of the interphase SPB (Fig. 6a). In Figure $6 b-f$, the relative positions of gold particles in five serial sections through a single interphase SPB are shown; the features of note in these five sections are superimposed in Figure $6 \mathrm{~g}$. Whereas the Cut12 epitopes were evenly distributed al ong the face of the SPB adjacent to the membrane, the Pk epitope was localized to only one side.

The cut $12^{+}$locus is allelic to stf1.1

Database comparisons of the cut $12^{+}$nucl eotide sequence reveal ed $100 \%$ identity of nucleotides $450-588$ downstream of the cut $12^{+}$stop codon with nucleotides 1-139
Figure 4. Characterization of anti-Cut12 antibodies and immunofluorescence localization of Cut12. (a) Affinity-purified rabbit antibodies against amino acids 33-548 of the Cut12 protein fused to GST were used to probe Western-blotted extracts from cut12.d1 cells (1), wild-type cells (2), cells overexpressing a full length cut $12^{+}$CDNA from the $n m t 1^{+}$promoter (3), or cells in which the wild-type cut $12^{+}$gene had been replaced with a version bearing the GFP tag inserted at methionine 33 of the cut $12^{+}$sequence (4), thereby causing a shift in predicted molecular weight of the Cut12 protein from 62 to 89 kD. (b) Immunolocalization of the Cut12 protein through the cell cycle. Wild-type fission yeast cells were grown to mid log phase, processed for immunofluorescence, and stained with antiCut12 and anti-tubulin antibodies. (Top) Cell outline and position of chromatin as revealed by DAPI; (middle) anti-tubulin staining; (bottom) anti-Cut12 staining. (I) interphase; $(P)$ prophase; $(M)$ metaphase; $(A A)$ anaphase $A$; $(A B)$ anaphase $B$; $(P A A)$ postanaphase array. Interphase cells were found to contain a single dot of anti-Cut12 staining associated with the interphase chromatin, whereas in mitotic cells anti-Cut12 staining was localized to the spindle poles. Scale bar, $10 \mu \mathrm{m}$. 
a
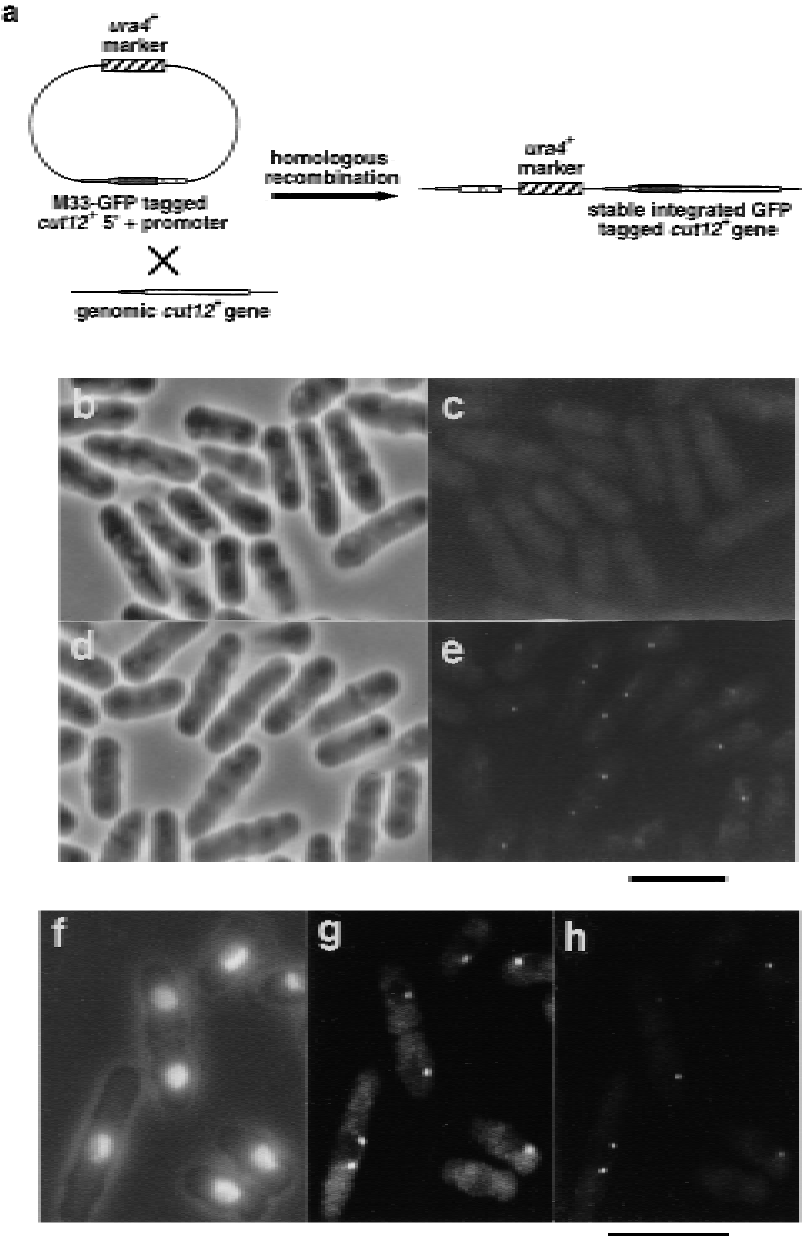

Figure 5. Localization of the Cut12 protein by use of GFP. (a). The wild-type cut $12^{+}$gene was replaced with a version bearing the GFP protein by homologous recombination with a plasmid containing the $5^{\prime}$ regi on of the cut $12^{+}$gene tagged at methionine 33 with the GFP CDNA. (b-e). Wild-type cells and cells bearing the GFP-tagged cut $12^{+}$gene were removed from culture and examined by phase microscopy $(b, d)$ and fluorescence microscopy with standard FITC filters to reveal GFP fluorescence $(c, e)$. $(b, c)$ Wild-type cells; $(d, e)$ Cut12-GFP tag cells. Cells carrying the integrated GFP-tagged cut $12^{+}$gene contained one or two dots of GFP fluorescence that were absent from wild-type cells. Scale bar, $10 \mu \mathrm{m}$. (f-h). Cells carrying integrated GFP-tagged cut $12^{+}$were processed for immunofluorescence and stained with anti-Sad1 antibodies. (f) Cell outline and chromatin revealed by DAPI; (g) Sad1 localization; (h) GFP-Cut12 localization. The GFP-Cut12 and Sad1 signals were found to col ocalize in both interphase and mitotic cells. Scale bar, $10 \mu \mathrm{m}$.

of the gtp $1^{+}$gene, which encodes a putative GTP binding protein (Hudson and Young 1993). The gtp $1^{+}$gene was cloned by virtue of its lying immediately ( 449 nucleotides) downstream of the mitotic control gene stf1 ${ }^{+}$ (Hudson et al. 1990; Hudson and Young 1993).

The $\operatorname{cdc} 25^{+}$gene of S. pombe encodes a tyrosine phosphatase that activates the $\mathrm{p} 34^{\mathrm{cdc} 2} / \mathrm{cyclin} \mathrm{B}$ kinase at the $\mathrm{G}_{2}$ to $M$ transition by catalyzing the removal of inhibitory phosphorylation on tyrosine 15 of p34 ${ }^{\text {cdc2 }}$ (Russell and N urse 1986; Dunphy and Kumagai 1991; Gautier et al. 1991; Kumagai and Dunphy 1991; Strausfeld et al. 1991). Mutants lacking Cdc25 function replicate their DNA but fail to activate the mitotic $\mathrm{p} 34^{\mathrm{cdc}} /$ cyclin $\mathrm{B}$ kinase, and become arrested in the $G_{2}$ phase of the cell cycle with an interphase array of microtubules (Russell and Nurse 1986; Hagan and Hyams 1988). stf1.1 is a semidominant mutation that allows loss-of-function mutants in $\mathrm{cdc} 25^{+}$, including a cdc $25^{+}$gene disruption, to successfully divide (Hudson et al. 1990). Our finding that both cut $12^{+}$and stf $1^{+}$appear to lie immediately upstream of the same gene indicated that the cut $12^{+}$and stf $1^{+}$genes may be identical .

We crossed a cdc25.22 mutant in which the cut $12^{+}$ locus was marked with the $\mathrm{ura}^{+}{ }^{+}$gene with a cdc25.22 stf1.1 double mutant. In 30 tetrads we found no $\mathrm{Ura}^{+}$ $\mathrm{Cdc}^{+}$spores, corresponding to a linkage of within $1.7 \mathrm{~cm}$ between the Ura4+-tagged cut12+ locus and the stf1.1 locus. The cut12 ${ }^{+}$gene was amplified from the stf1.1 strain and the entire ORF of the PCR product sequenced directly. We identified a single base change (G-T) in codon 71 of the cut $12^{+}$sequence in four independent PCR reactions, which would result in the replacement of glycine 71 with a val ine residue. Although expression of a plasmid borne cut $12^{+} \mathrm{CDN}$ A from the pREP81 plasmid was unable to rescue the ts cdc25.22 defect, expression of the cut12.G71V mutant CDNA suppressed the cdc25.22 defect at $30^{\circ} \mathrm{C}$, but not at $33^{\circ} \mathrm{C}$ or $36^{\circ} \mathrm{C}$ (Fig. $7 \mathrm{~b}$ ). This level of suppression is equival ent to that seen in a cdc25.22/cdc25.22 stf1 $1^{+}$stf1.1 diploid, which is viable up to $32^{\circ} \mathrm{C}$ (Hudson et al. 1990). Therefore, cut $12^{+}$and stf $1^{+}$are allelic, and a single mutation of glycine 71 to valine in cut $12^{+}$can suppress the requirement for $\mathrm{Cdc} 25$ in mitotic initiation. The cut12.G71V mutation did not alter the localization pattern of Cut12 as determined by immunofluorescence in either a wild-type or cdc25.22 background at $25^{\circ} \mathrm{C}$ or $36^{\circ} \mathrm{C}$ (data not shown).

The stf1.1 cdc25.22 mutant forms defective mitotic spindles at high temperatures

The ability of stf1.1 to bypass the requirement for $\mathrm{Cdc} 25$ is incomplete. The genomic mutation stf1.1 could suppress cdc25.22 and a del etion of the cdc $25^{+}$gene only up to $35^{\circ} \mathrm{C}$, whereas at $37^{\circ} \mathrm{C}$, both double mutants formed small colonies that contained aberrantly dividing cells (Hudson et al. 1990). To determine the basis of the lethality at the higher temperature, the single mutants stf1.1 and cdc25.22, and the double mutant stf1.1 cdc25.22, were grown at $25^{\circ} \mathrm{C}$ and shifted to $37^{\circ} \mathrm{C}$. On shift to $37^{\circ} \mathrm{C}$, cdc25.22 cells arrested cell cycle progression with interphase microtubules and a single nucleus characteristic of $\mathrm{G}_{2}$ (Fig. 8a,d,g) whereas stf1.1 cells continued to form normal spindles and divide (Fig. 8b,e,h). stf1.1 cdc25.22 cells disassembled the interphase cytoskeleton, condensed their chromosomes, and formed aberrant star shaped spindles that originated from a single large focus of Sad1 staining (Fig. 8c,f,i). The presence of an enl arged Sad1 focus caused a characteristic hol e in the center of the mi crotubule array. Thus, whereas the stf1.1 
Figure 6. Electron microscopic localization of Cut12 protein within the SPB. (a) Immunogold staining of a section through an SPB by use of antibodies to the Pk epitope tag and a polyclonal anti-Cut12 antibody. Secondary antibodies were conjugated to gold particles of $5 \mathrm{~nm}(\mathrm{Pk})$ and 10 nm (Cut12). (S) Spindle pole body; (M) cytoplasmic microtubule laterally associated with the SPB; (N) nuclear envelope. The Cut12 epitopes were localized specifically to the inner face of the main body of the cytoplasmic SPB, adjacent to the nuclear envelope. The Pk epitope tag appeared localized more to one side of the inner face of the SPB. (b-f) Five serial sections through the single SPB shown in a were stained with antibodies to the Pk epitope tag and polyclonal antibodies to the Cut12 protein. Secondary antibodies were conjugated to gold particles of $5 \mathrm{~nm}(\mathrm{Pk})$ and $10 \mathrm{~nm}$ (Cut12). (g) Immunogold localization of Cut12 epitopes in serial sections through a single SPB in the PK epitope tagged cut $12^{+}$strain. The five serial sections shown in b-f were superimposed. (Green dots) $10 \mathrm{~nm}$-gold particles (antiCut12); (blue dots) $5 \mathrm{~nm}$ gold particles (anti-Pk); (yellow lines) nuclear envelope; (red lines) SPB; (blue line) cytoplasmic microtubule.
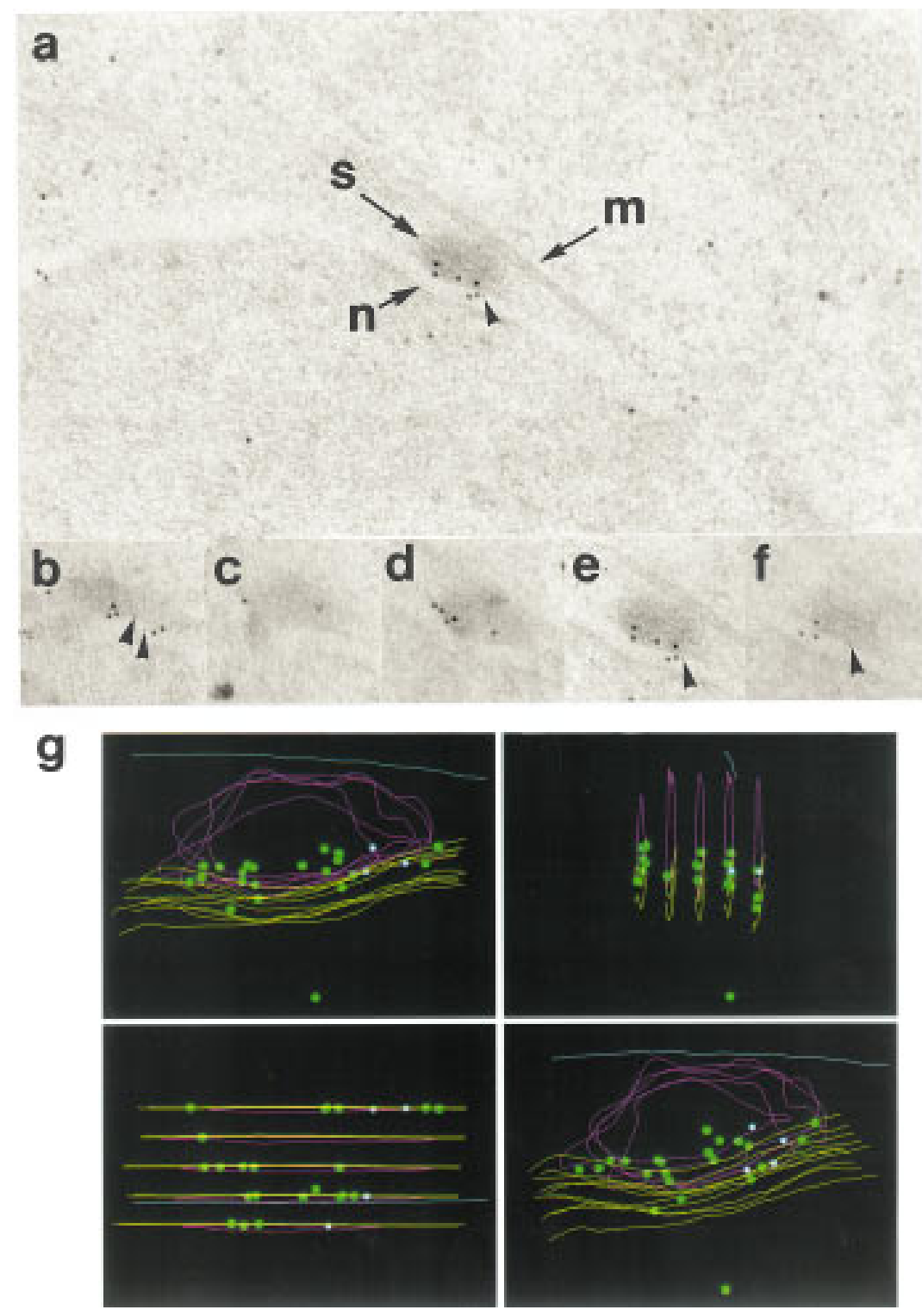

mutation can bypass the requirement for $\mathrm{Cdc} 25$ at all temperatures and allow commitment to mitosis, at $37^{\circ} \mathrm{C}$ the spindles that are formed in the stf1.1 mutant in the absence of $\mathrm{Cdc} 25$ function are defective.

\section{cdc25.22 exacerbates the spindle formation defect} in cut 12.1

As a semidominant mutation in cut12 can bypass the requirement for $\mathrm{Cdc} 25$, we determined the effect of combining the loss-of-function cut12.1 mutation with cdc25.22. Although the single cdc25.22 and cut12.1 mutants were viable up to $30^{\circ} \mathrm{C}$, the double mutant cut12.1 cdc 25.22 was viable only at $20^{\circ} \mathrm{C}$ and unable to grow at temperatures of $25^{\circ} \mathrm{C}$ and above (Fig. 9a). On shift to $25^{\circ} \mathrm{C}$, the cut $12.1 \mathrm{cdc} 25.22$ cells entered mitosis and formed monopolar spindles that arose from a weakly staining focus of Sad1 staining (Fig. 9b-d). This pheno- type is identical to that of the single cut 12.1 mutant on shift from $25^{\circ} \mathrm{C}$ to $36^{\circ} \mathrm{C}$ (Fig. 1). At $36^{\circ} \mathrm{C}$, the double mutant cut12.1 cdc25.22 arrested with interphase microtubules characteristic of the $\mathrm{G}_{2}$ arrest seen in the single mutant cdc25.22 (data not shown). Thus, the presence of the cdc25.22 mutation exacerbates the spindle defect in the cut12.1 mutant.

\section{Discussion}

We have shown that loss-of-function of the SPB component Cut12 leads to the formation of defective monopolar spindles. Unexpectedly, a semidominant mutation in cut $12^{+}$can bypass the requirement for the essential MPF activating tyrosine phosphatase Cdc25 (Hudson et al. 1990, 1991). This was suprising as Cut12 is therefore an SPB component that is both essential for bipolar spindle formation and capable of influencing the require- 
a

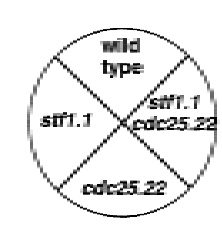

b

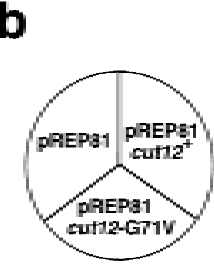

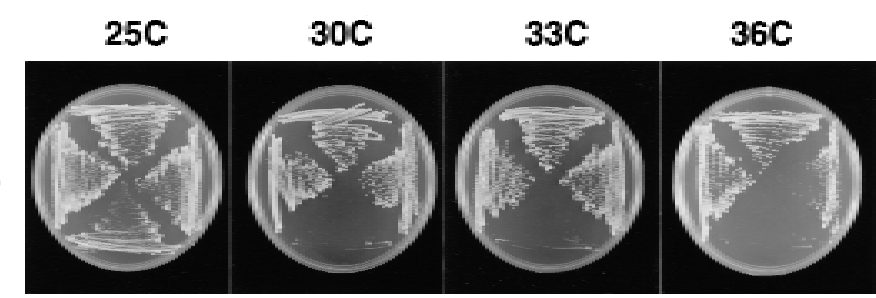

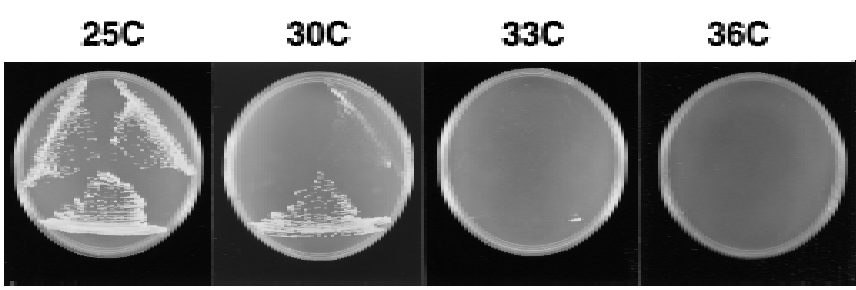

Figure 7. The cut $12^{+}$and $\mathrm{stf1} 1^{+}$genes are identical. (a) Temperature sensitivity of the cdc25.22 and stf1.1 single mutants and a cdc25.22 stf1.1 double mutant. Cells were streaked onto complete medium at $25^{\circ} \mathrm{C}$, $30^{\circ} \mathrm{C}, 33^{\circ} \mathrm{C}$, and $36^{\circ} \mathrm{C}$. The stf1.1 mutation allowed growth of a cdc25.22 mutant on complete medium at all four temperatures tested, although at $36^{\circ} \mathrm{C}$ growth was slow relative to wild-type cells, and colony size is irregular. (b) Suppression of cdc25.22 by a point mutation in the cut $12^{+}$gene. cdc25.22 mutant cells carrying a pREP81 plasmid containing no insert, a full-length wild-type cut $12^{+}$cDNA, or the mutant cut12.G71V CDNA, were streaked onto minimal medium lacking thiamine at $25^{\circ} \mathrm{C}, 30^{\circ} \mathrm{C}, 33^{\circ} \mathrm{C}$, and $36^{\circ} \mathrm{C}$. Although cdc 25.22 cells carrying a blank plasmid or the wild-type cut $12^{+}$gene were unable to form colonies at $30^{\circ} \mathrm{C}$, cdc25.22 cells carrying the cut $12 . \mathrm{G} 71 \mathrm{~V}$ mutant CDN A were able to grow at $30^{\circ} \mathrm{C}$ but not $33^{\circ} \mathrm{C}$. This is consistent with the ability of a cdc25.22/ cdc25.22 stf1.1/stf1 ${ }^{+}$diploid to grow at temperatures bel ow $33^{\circ} \mathrm{C}$ (Hudson et al. 1990).

ment for a normally essential inducer of mitosis. Because the loss-of-function phenotype defines cut $12^{+}$as a cut gene, whereas the stf1.1 mutation is a gain-of-function mutation, we will refer to the cut $12^{+} / \mathrm{stfl}^{+}$gene as cut $12^{+}$.

Loss of Cut12 function leads to formation of monopolar spindles

The interphase fission yeast SPB consists of two components. The main body of the SPB resides in the cytoplasm and is separated from the mitotic spindle microtubule nucl eator $\gamma$-tubulin by the nuclear envel ope (Ding et al. 1997). Mitotic activation of the SPB is accompanied by localized nuclear envelope breakdown and association of these two el ements. In actively dividing cells that lack Cut12 function, Sad1 localization did not correlate with microtubul e nucleating activity. This may indicate that these two elements of the mitotic SPB remain independent in the absence of Cut12.

In cut12.1, monopol ar spindles arose from the weaker of the two Sad1 staining foci, whereas in germinating cut12.d1 spores monopolar spindles were not associated with either of the two equally staining Sad1 foci. The differential effect of the cut12.1 mutation on the two SPBs suggests that Cut12 is incorporated into the duplicated SPBs in a conservative fashion, and that the Cut12 protein incorporated into the SPB in the cell cycle prior to the temperature shift is stabilized. Differential behavior of the duplicated SPBs is also illustrated by the activation of the cytokinesis regulating GTPase Spgl on only one of the two anaphase SPBs (Sohrmann et al. 1998). As the two SPBs appear to be generated by fission of a larger precursor to two smal ler structures (Ding et al. 1997), the nonequivalence between the two daughter
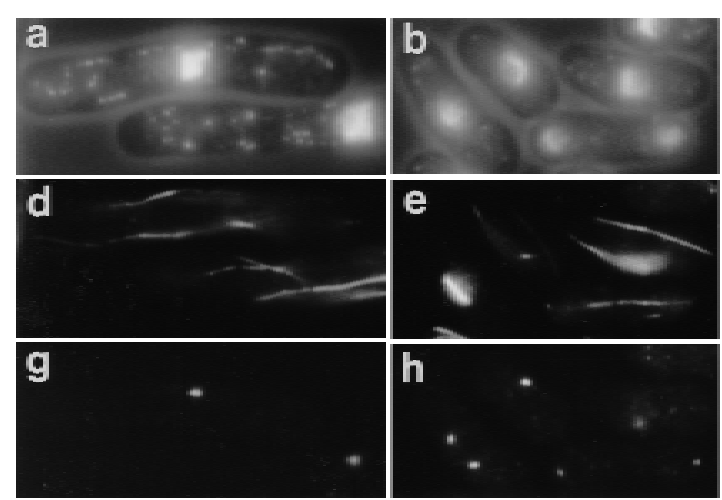

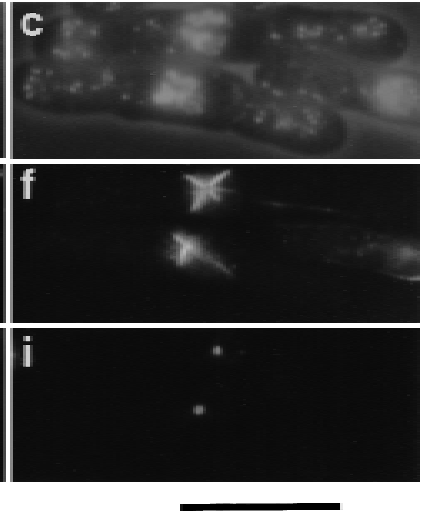

Figure 8. The stf1.1 mutant has a temperature-sensitive spindle defect in a cdc25.22 background. (a-i) Immunofluorescence analysis of the $\operatorname{cdc} 25.22$ and stf1.1 single mutants and the double mutant cdc25.22 stf1.1. Cells were cultured in complete medium to mid-log phase at $25^{\circ} \mathrm{C}$ and then shifted to $37^{\circ} \mathrm{C}$, and processed for immunofluorescence analysis. (a-c) Phase/DAPI; (d-f) anti-tubulin staining; (g-i) anti-Sad1 staining. $(a, d, g)$ cdc25.22; (e,f,h) stf1.1; (c,f,i) cdc25.22 stf1.1. The single cdc25.22 mutant arrested with an interphase cytoskeleton characteristic of a $G_{2}$ cell, whereas the stf1.1 mutant continued to form normal spindles and divide. The double-mutant cdc25.22 stf1.1 formed aberrant starshaped spindles arising from a single large Sad1 focus within the cell. Scale bar, $10 \mu \mathrm{m}$. 
a
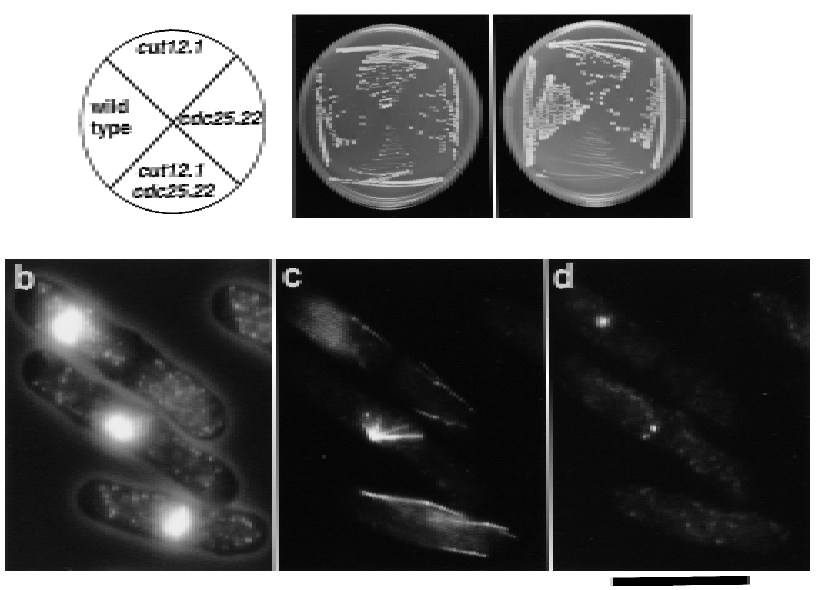

Figure 9. Synthetic lethal ity between cut12.1 and cdc25.22. (a) Temperature sensitivity of cdc25.22, cut12.1, and cdc25.22 cut12.1 mutants. Cells were streaked onto complete medium at $20^{\circ} \mathrm{C}$ and $25^{\circ} \mathrm{C}$. Although the single mutants cdc25.22 and cut12.1 both grew at $25^{\circ} \mathrm{C}$, the double mutant cdc 25.22 cut 12.1 was inviable at this temperature. (b-d) Immunofluorescence analysis of phenotype of the cdc25.22 cut12.1 mutants. Cells were cultured in complete medium at $20^{\circ} \mathrm{C}$ and then shifted to $25^{\circ} \mathrm{C}$ and processed for immunofluorescence. (b) Cell outline and chromatin; (c) anti-tubulin staining; (d) anti-Sad1 staining. On shift to $25^{\circ} \mathrm{C}$, the cdc 25.22 cut 12.1 mutant formed defective spindles. Although the cdc25.22 cut12.1 cells appeared to contain two foci of Sad1 staining, cells formed defective monopolar spindles that arose from the less bright staining Sad1 focus, as in the cut 12.1 mutant at $36^{\circ} \mathrm{C}$. Scale bar, $10 \mu \mathrm{m}$.

SPBs may be generated by localized incorporation of new material within a particular region of the SPB during growth; fission would then lead to the production of $a$ mature and a new SPB. The apparent asymmetry of exposure of amino-terminal epitopes of Cut12 within the SPB supports this possibility.

\section{cut12.G 71V bypasses the requirement for $\mathrm{Cdc} 25$}

The p34cdc2 kinase is subject to inhibitory phosphorylation on $\mathrm{T} 14$ and $\mathrm{Y} 15$ residues, and the removal of these inhibitory phosphates determines the timing of entry into mitosis (Gould and N urse 1989). In fission yeast this inhibitory phosphorylation is catalyzed in by the Weel kinase and a redundant Weel homolog Mik1 (Russell and Nurse 1987a; Featherstone and Russell 1991; Lundgren et al. 1991; Parker et al. 1993; Lee et al. 1994; Den Haese et al. 1995). The action of the Weel/Mik1 kinases is opposed by Cdc25 phosphatase (Fantes 1979; Russell and Nurse 1986), which dephosphorylates both T14 and Y15 in vitro (Dunphy and Kumagai 1991; Gautier et al. 1991; Kumagai and Dunphy 1991; Strausfeld et al. 1991).

The activity of C dc25 is stimulated by cell-cycle specific phosphorylation of certain sites (Ducommun et al. 1990; Moreno et al . 1990; Izumi et al . 1992; Kumagai and Dunphy 1992; Hoffmann et al. 1993; Izumi and Maller
1993). The Weel and Mik1 kinases are also subject to cell cycle-dependent phosphorylation that has been reported to inhibit the activity of the kinase (Russell and N urse 1987b; Coleman et al. 1993; Parker et al. 1993; Tang et al. 1993; Wu and Russell 1993; McGowan and Russell 1995; Mueller et al. 1995; Watanabe et al. 1995). Thus, phosphorylation of both $\mathrm{Cdc} 25$ and the opposing Weel/Mik1 kinases promotes the activation of p34 ${ }^{\text {cdc2 }}$ / cyclin B and onset of mitosis. Phosphorylation and inhibition of Weel is catalyzed by the action of the $\mathrm{Nim1/}$ Cdr1 kinase (Coleman et al. 1993; Parker et al. 1993; Wu and Russell 1993), and other unrel ated kinases including MPM 2 epitope kinases (Tang et al. 1993; Mueller et al. 1995). The stimulatory phosphorylation of $\mathrm{Cdc} 25$ can be accomplished in vitro by either the $\mathrm{p} 34^{\mathrm{cdc} 2} / \mathrm{cyclin} \mathrm{B} \mathrm{ki}-$ nase (Hoffmann et al. 1993; Izumi and Maller 1993) or by non-p34 ${ }^{\text {cdc2 }}$ kinases including MPM 2 epitope kinases such as the Xenopus PIx kinase (Kuang et al. 1994; Izumi and M aller 1995; Kumagai and Dunphy 1996). Biochemical studies in Xenopus have demonstrated the existence of a positive feedback loop involving p34 ${ }^{\mathrm{cdc} 2}$ and C dc25, in which $\mathrm{Cdc} 25$ may dephosphorylate and activate p34 ${ }^{\mathrm{cdc} 2} / \mathrm{cyclin} \mathrm{B}$, which then phosphorylates and stimulates Cdc25 to, in turn, dephosphorylate further p34 ${ }^{\mathrm{cdc} 2}$ / cyclin B, leading to the rapid amplification of a small quantity of MPF and entry into mitosis (Izumi and Maller 1993; Hoffmann et al. 1993). This amplification loop could be triggered by the p34 ${ }^{\mathrm{cdc}} \mathrm{2}$ independent phosphorylation and activation of $\mathrm{Cdc} 25$, or by the phosphorylation and inhibition of Weel/ Mik1. The loop may also be triggered by the generation of a fraction of p34 ${ }^{\mathrm{cdc} 2} / \mathrm{cyclin} B$ that does not require Cdc25 for activation or that is not sensitive to inhibition by Weel/M ik1.

Within this context, a number of models can be considered that may account for the ability of a semidominant mutation in an SPB component to bypass the requirement for $\mathrm{Cdc} 25$. Cut12 is unlikely to solely regulate the activity of $\mathrm{Cdc} 25$, as stf1.1 can suppress a complete loss of Cdc25 activity arising from the disruption of the $\mathrm{cdc} 25^{+}$gene (Hudson et al. 1990, 1991). Cut12 is also unlikely to solely regulate Weel, as stf1.1 is additive with weel.50 in suppression of cdc25.22 and is sensitive to the overexpression of weel $^{+}$(Hudson et al. 1990). Cut12 might, however, directly or indirectly regulate the activities of both Weel and Mik1, or possibly interact with a dual regulator of Cdc25 and Weel/Mik1 function, a role proposed for the Xenopus PIx MPM 2 kinase (Kumagai and Dunphy 1996; Lane and N igg 1996). In both these models, Cut12 may promote mitosis in the absence of $\mathrm{Cdc} 25$ function by down-regulating both Weel and $\mathrm{M} i \mathrm{k} 1$, thereby relieving the negative restraint that holds a cdc25.22 mutant in $\mathrm{G}_{2}$. Cut12 could also relieve this restraint by promoting $\mathrm{Y} 15$ dephosphorylation of $\mathrm{p3} 4^{\mathrm{cdc} 2}$ by another tyrosine phosphatase, such as the tyrosine phosphatase Pyp3 (Millar et al. 1992). Pyp3 is unrelated to $\mathrm{Cdc} 25$ but may act cooperatively with Cdc25 to dephosphorylate Y15 of p34 cdc2 (Millar et al. 1992). However, the stf1.1 mutation is unlikely to bypass loss of $\mathrm{Cdc} 25$ function by increasing pyp3 ${ }^{+}$activity, as loss of pyp3 ${ }^{+}$function does not appear to lead to Cut 
divisions (Millar et al. 1992). In a simpler model stf1.1 may allow the formation of p34 ${ }^{\mathrm{cdc}} /$ cyclin $B$ complexes at the SPB that are not subject to inhibition by Weel/ Mik1 kinases.

\section{Potential interactions between Cut12 and MPF}

Genetic studies in fission yeast have shown that the requirement for $\mathrm{Cdc} 25$ function can be altered by mutation of the $\mathrm{cdc} 2^{+}$gene and its cyclin B-type partner encoded by the cdc13 $13^{+}$gene. Like cut12.G71V, a gain-offunction mutation in $\mathrm{cdc} 2^{+}$termed $\mathrm{cdc} 2.3 \mathrm{w}$ can bypass the requirement for $\mathrm{Cdc} 25$ activity at the $\mathrm{G}_{2}$-to-M transition (Carr et al. 1989; Gould et al. 1990; MacN eill and Nurse 1993), whereas loss-of-function mutations in $\mathrm{cdc} 3^{+}$are, like cut12.1, synthetically lethal with cdc25.22 (Bueno and Russell 1993). The genetic interaction between cdc25.22 and both loss- and gain-of-function al leles in cut $12^{+}$are consistent with Cut12 acting as a regulator or substrate of the $\mathrm{p} 34^{\mathrm{cdc}} / \mathrm{cyclin} B$ kinase. Both p34 ${ }^{\mathrm{cdc} 2}$ and $\mathrm{Cdc} 13$ have been localized to the SPB (Alfa et al. 1990), and mutations in the $c d c 2^{+}$and $c d c 13^{+}$ genes have been identified that can specifically inhibit chromosome segregation but not other events of mitosis such as chromosome condensation and septation (Labib et al. 1995; Berry and Gould 1996; Gould and Feoktistova 1996). cdc2.Y15T and cdc13.A381V are perhaps particularly relevant in this regard, as these mutant proteins may be unable to promote spindle formation because of a defective interaction with a regulatory subunit that is specifically required for this process (Berry and Gould 1996; Gould and Feoktistova 1996). It has also been suggested that a higher threshold level of $\mathrm{p} 34^{\mathrm{cdc} 2} / \mathrm{cycl}$ in $B$ kinase activity may be required for mitotic spindle formation than for chromosome condensation and septation, and that mutants such as Cdc2.Y15T may be unable to attain this level of activity (Gould and Feoktistova 1996). Therefore, Cut12 may be a limiting substrate normally phosphorylated only when the p34 ${ }^{\mathrm{cdc}} /$ cyclin B activity reaches the level required for bi pol ar spindle formation. The cut12.G71V mutation lies between the closely apposed amino-terminal M AP kinase and p34 ${ }^{\text {cdc2 }}$ consensus sites, and Cut12.G71V may conceivably mimic an activated form of Cut12 and allow progression through mitosis in the presence of a lower level of p34 ${ }^{\mathrm{cdc}} /$ cyclin B kinase activity. Loss-of-function mutants in cut $12^{+}$undergo chromosome condensation and septation without forming a bipolar spindle. A similar phenotype to cut12.1 is seen in mutants of $A$. nidulans that enter mitosis in the absence of NIMA function, a known mitotic substrate of $p 34^{\mathrm{cdc} 2} / \mathrm{cyclin} B$ kinase (Osmani et al. 1991a; Ye et al. 1995). Whereas the nimA 5 mutant normally arrests in $G_{2}$ with duplicated SPBs and high p34 ${ }^{\mathrm{cdc}} /$ cyclin B kinase activity, the bimE7 nimA 5 double mutant escapes this $G_{2}$ arrest and attempts an aberrant mitosis with defective SPBs (Oakley and M orris 1983; Osmani et al. 1991a,b). Thus, loss-of-function mutations in downstream effectors of p34 ${ }^{\text {cdc2 }}$ function may uncouple the normally coordinated events of mitosis such as spindle formation and chromosome condensation and septation.

Whatever the precise mechanism by which stf1.1 bypasses the requirement for $\mathrm{Cdc} 25$, the demonstration that an essential component of the SPB can influence the requirement for activators of $\mathrm{p} 34^{\mathrm{cdc} 2} / \mathrm{cyclin} \mathrm{B}$ highlights the importance of events at the spindle pole to cell cycle progression in general.

\section{Materials and methods}

Cell culture and strains

Cell culture and maintenance was carried out according to Moreno et al. (1991). All Cut12 localization experiments, and the analysis of spindle formation defects in cut12.1, cut12.1 cdc25.22, and stf1.1 cdc25.22 mutants, were carried out on cells cultured in rich YES medium. The cut $12^{+}$del etion and overexpression analyses, plus all cell length measurements, were carried out on cells grown in Edinburgh minimal medium (EMMG) that is equival ent to EM M 2 (M oreno et al. 1991) but substitutes 5 grams/liter glutamic acid for 5 grams/liter ammonium acetate as a nitrogen source. Synchronous cultures were generated by size selection of small $\mathrm{G}_{2}$ cells on a lactose gradient as described previously (Hagan and Yanagi da 1997). The strains used in this paper are shown in Table 1.

Isolation and sequencing of the cut $12^{+}$gene

Standard DNA manipulations were carried out according to Sambrook et al. (1989). The cut $12^{+}$gene was isol ated by complementation of the temperature-sensitive mutant. Fourteen transformants carrying five complementing plasmids were isolated from screens of two genomic S. pombe libraries (the generous gift of Dr. A. Carr; Barbet et al. 1993). These plasmids had an overlapping region of $\sim 2.8 \mathrm{~kb}$, including the minimum complementing 2.0-kb EcoRV-Pvull fragment. Integration of a plasmid containing a portion of the cloned DN A linked to the $u{ }^{+} 4^{+}$gene by homologous recombination showed that the cloned region contained the cut $12^{+}$gene, as no recombination was observed between the cut 12.1 and ura $^{+}{ }^{+}$in $>1100$ spores ( $N$ urse 1975). A 1.0-kb HindlII-EcoRV and a 2.0-kb HindlII fragment that together completely covered this minimum complementing region were cloned into the Bluescript plasmid to generate the pSCUT12-1 and pSCUT 12-2 plasmids, respectively, and nested deletions made by use of exonuclease III. DN A sequencing was performed on both strands by the manual dideoxy method with T7 DN A polymerase. The presence of the predicted 42-bp intron was confirmed by sequencing a clone isolated by PCR amplification from a pREP1 based CDNA library (a gift from Dr. C. N orbury, John Radcliffe Hospital, Institute of M olecular M edicine, ICRF, M ol ecular Oncology Laboratory, Oxford, UK) by use of primers (5'-TTCAGAGATCCGATAGAATGTCAG-3') and (5'-CCTTCGTCTTCTCCTTTCCTCTAATC-3'). The cut12.1 mutant version of the cut $12^{+}$gene was isolated by PCR amplification with two primers (5'-CGACTAATACGGCCTTTTACAAGCC-3') and (5'-CATGCAGAACAATTCAGAGATCCG$\left.3^{\prime}\right)$. PCR products were sequenced directly by a manual T7 DNA polymerase procedure. Where a mutation was identified, that region of the gene was sequenced again from four independent $P C R$ reactions.

Construction of the cut12.d1 deletion

A 4-kb genomic Pst1-Kpnl fragment from the shortest cut12.1 complementing genomic clone was cloned into Pst1-Kpnl-di- 
Table 1. Strains used in this study

\begin{tabular}{|c|c|c|}
\hline Strain & Genotype & Origin \\
\hline IH310 & leu1.32/leu1.32 ade6.M210/ade6.M216 ura4.d18/ura4.d18 $\mathrm{h}^{-} / \mathrm{h}^{+}$ & lab stock \\
\hline IH 365 & leu1.32 ura4.d18 $\mathrm{h}^{-}$ & lab stock \\
\hline IH566 & cdc25.22 leu1.32 ura4.d18 $\mathrm{h}^{-}$ & lab stock \\
\hline IH571 & cut12.M33GFP:ura4 ${ }^{+}$leu1.32 ura4.d18 $\mathrm{h}^{-}$ & this study \\
\hline IH572 & cut12.dl/cut12 ${ }^{+}$leu1.32/leu1.32 ade6.M210/ade6.M216 ura4.d18/ura4.d18 $\mathrm{h}-\mathrm{h}^{+}$ & this study \\
\hline IH596 & cut12.1 leu1.32 ura4.d18 $\mathrm{h}^{-}$ & this study \\
\hline IH 666 & stf1.1 leu1.32 $\mathrm{h}^{+}$ & Hudson et al. (1990) \\
\hline IH 667 & stf1.1 cdc25.22 leu1.32 ura4.d18 h90 & Hudson et al. (1990) \\
\hline $\mathrm{IH} 741$ & stf1.1 cdc25.22 leu1.32 ura4.d18 $\mathrm{h}^{-}$ & Hudson et al. (1990) \\
\hline $\mathrm{IH} 744$ & cut12.M33Pk:ura4 ${ }^{+}$leu1.32 ura4.d18 $\mathrm{h}^{-}$ & this study \\
\hline IH 751 & cdc25.22 cut12.M33Pk:ura4 ${ }^{+}$leu1.32 ura4.d18 $\mathrm{h}^{-}$ & this study \\
\hline $\mathrm{IH} 970$ & cdc25.22 leu1.32 ura4.d18 pREP81-cut12.G71V $\mathrm{h}^{-}$ & this study \\
\hline IH972 & cdc25.22 leu1.32 ura4.d18 pREP81-cut12 ${ }^{+} \mathrm{h}^{-}$ & this study \\
\hline $\mathrm{IH} 1080$ & cdc25.22 leu1.32 ura4.d18 pREP81 $\mathrm{h}^{-}$ & this study \\
\hline $\mathrm{IH} 1110$ & cut12.d1 ade6 leu1.32 pREP81-cut12 ${ }^{+} \mathrm{h}^{-}$ & this study \\
\hline $\mathrm{IH} 1120$ & stf1.1 leu1.32 ura4.d18 $\mathrm{h}^{-}$ & this study \\
\hline $\mathrm{IH} 1225$ & leu1.32 ura4.d18 pREP1 $\mathrm{h}^{-}$ & this study \\
\hline $\mathrm{IH} 1226$ & leu1.32 ura4.d18 pREP1-cut12 ${ }^{+} \mathrm{h}^{-}$ & this study \\
\hline $\mathrm{IH} 1227$ & cut12.1/cut12 ${ }^{+}$leu1.32/leu1.32 ade6.M210/ade6.M216 ura4.d18/ura4.d18 $\mathrm{h}^{-} / \mathrm{h}^{+}$ & this study \\
\hline
\end{tabular}

gested pU 19 to generate the plasmid pDCUT12-1. A 1.6-kb Ppulol fragment containing all of the cut $12^{+}$coding sequence, with the exception of the first 10 amino acids, was removed from pDCUT12-1 and replaced with a Notl linker (GCGGCCGC) to generate pDCUT12-2. A 1.8-kb Acclll fragment containing the ura $4^{+}$gene (Barbet et al. 1993) was inserted into the linker to generate pDCUT 12-3. A 4-kb fragment containing the cut $12^{+}$gene deleted by the $\mathrm{ura}^{+}$gene was purified from $\mathrm{pD}$ CUT12-3 and used to transform a diploid $\left(\mathrm{h}^{+} / \mathrm{h}^{-}\right.$leu1-32/leu132 ura4-d18/ura4-d18 ade6-M210/ade6-M216). Stable U ra+ diploids that had the desired replacement determined by genomic Southern hybridization were selected. Probing with a $2.0-\mathrm{kb}$ HindlII fragment containing the $3^{\prime}$ region of the cut $12^{+}$gene reveal ed a 3.7-kb Bglll fragment in the del etion diploid in addition to the 1.7- and 2.0-kb bands observed in wild type.

Construction of a full-length cut $12^{+}$CDNA

for overexpression studies

pREP 1 and pREP 81 were used to express cut $12^{+}$under the control of the thiamine repressible $n m t^{+}$promoter (Basi et al. 1993; Maundrell 1993). For the construction of the $\mathrm{Ndel}$ site (CATATG) at the initiator codon, the plasmid pSCUT12-1 was digested with $\mathrm{N}$ sil. Two oligonucel otides (5'-ATATGTCAGAAACTTTGAACACTCCGCCAACC-3') and (5'-TAGGTTGGCGGAGTGTTCAAAGTTTCTGACA-3') were allowed to anneal to generate a linker that was inserted at the $\mathrm{N}$ sil site, thereby generating a clone bearing the $5^{\prime}$ region of cut $12^{+}$gene with two copies of the cut $12^{+}$start codon and the first 10 amino acids, in which the original start codon was followed by the intron, and the newly introduced second start codon had an $\mathrm{Ndel}$ site at the ATG. The original $\mathrm{N}$ del site at nucleotides 29-34 of the cut $12^{+}$coding sequence was also removed by this procedure. The plasmid was designated pSCUT 12-1/ M 1N del. A BgllI-EcoRV fragment from pSCUT12-1/M1Ndel was subcloned back into the $4-\mathrm{kb}$ genomic cut $12^{+} \mathrm{cl}$ one. This construct was then digested with $\mathrm{Ndel}$ and Pvull, to yield a $2.2-\mathrm{kb}$ fragment bearing the full length cut $12^{+}$cDN A and $300 \mathrm{bp} 3^{\prime}$ of the gene. The Ndel-Pvull fragment was then inserted into $\mathrm{Ndel}-$ Smal-digested pREP plasmids.
Construction of an integrated GFP-tagged version of the cut $12^{+}$gene

The GFP tag was inserted at an N del site created at methionine 33 of the cut $12^{+}$sequence. The PSCUT 12-1 plasmid was used as a template for site directed mutagenesis by use of the primer 5'-GCCTGTTACACATATGTCCTCTTAC-3', and the resulting mutant clone (pSCUT12-1/M $33 \mathrm{~N} \mathrm{del}$ ) was sequenced entirely between the initiator codon and the HindlII site to confirm that no errors had been introduced during the mutagenesis procedure. The GFP CDNA as an N del fragment (R. Craven, D. Griffiths, K. Sheldrick, R. Randall, I. Hagan, and A. Carr, in prep.) was then inserted into this position to give PSCUT12-1/ M 33GFP. To create the plasmid for integrative transformation of cut12+-GFP into the genome, the HindlII-EcoRV fragment was then cloned into HindlII-EcoRV-digested Bluescript with ura $4^{+}$inserted at the Notl site to form pINTCUT 12-1/M 33GFP.

Construction of an integrated $\mathrm{Pk}$ epitope-tagged version of the cut $12^{+}$gene

For epitope tagging the cut $12^{+}$gene, we used a pREP42 plasmid (pREP42-PkN) bearing three copies of the Pk epitope tag (amino acid sequence IPNPLLGLD; R. Craven, D. Griffiths, K. Shel drick, R. Randal I, I. Hagan, and A. Carr, in prep.), inserted as an Ndel cassette at the multicloning site. The cassette also bears an internal $\mathrm{N}$ col site following the second copy of the tag; hence, it is possible to link $\mathrm{N}$ col-digested genes to the Pk tag bearing pREP42 plasmid, and then re-excise the gene al ong with two copies of the Pk tag by Ndel digest. An N col site was inserted at $\mathrm{M} 33$ of the cut $12^{+}$sequence by site-directed mutagenesis on the pSCUT 12-1 plasmid by use of the primer 5'-GCCTGTTACAACCATGGCCTCTTAC- $3^{\prime}$, and the resulting clone (pSCUT 12-1/M 33N col) sequenced between the initiator codon and the HindlII site. A Bglll-EcoRV fragment was subcloned back into the 4-kb genomic cut $12^{+}$cl one of pDCUT 12-1 to form pDCUT 12-1/M 33N col. This construct was then digested with $\mathrm{Ncol}$ and Pvull, which yields a 2.2-kb fragment bearing a truncated form of the cut $12^{+}$gene encoding amino acids 33-548, along with $\sim 300$ bp $3^{\prime}$ of the gene, which was inserted into 
pREP42-PkN. The regeneration of the full length cut $12^{+}$gene from the truncated version in pREP42-PkN vector was complicated by the $\mathrm{Ndel}$ site that lies immediately upstream of the EcoRV site in pDCUT12-1. To circumvent this problem, a 1.6$\mathrm{kb} \mathrm{N}$ sil fragment that lacks the internal $\mathrm{N}$ del site was excised from pDCUT12-1/M 33N del and cloned into the Bluescript plasmid to give pDCUT12-4. The $5^{\prime}$ region of the tagged truncated cut $12^{+}$gene was then isolated from pREP42-PkN by N delBglll digest, and the $0.5-\mathrm{kb}$ fragment produced ligated to $\mathrm{N}$ delBgllI-digested pDCUT12-4. The N sil fragment from the resulting plasmid was then cloned back into pDCUT12-1, thereby generating a plasmid bearing the full length cut $12^{+}$gene with two copies of the Pk epitope tag inserted at methionine 33, termed pDCUT12-1/M33Pk. The HindIII-EcoRV fragment from this plasmid was then cl oned into HindlII-EcoRV-digested Bluescript with ura $4^{+}$inserted at the Notl site to create the plasmid for integrative transformation of $\mathrm{Pk}$-tagged cut $12^{+}$into the genome, termed pINTCUT12-1/M 33Pk.

Isolation of the stf1.1 mutant locus by PCR and cloning PCR products

The stf1.1 mutant version of the cut $12^{+}$gene was isolated by PCR amplification according to the protocol described for cut12.1. To clone the stf1.1 mutant gene, a $0.5-\mathrm{kb}$ Nsil-Bgl II fragment was purified from the PCR product and ligated to N silBglll-digested pSCUT12-1/M1Ndel. The resulting clone was manually sequenced to confirm the presence of the stf1.1 mutation in codon 71. To recreate full-length clones from this mutated construct, a Bglll-EcoRV fragment was subcloned back into the $4-\mathrm{kb}$ genomic cut $12^{+} \mathrm{cl}$ one, thereby regenerating a fulllength stf1.1 mutant version of cut $12^{+}$. This construct was then digested with $\mathrm{N}$ del and Pvull, to yiel d a 2.2-kb fragment bearing the full-length cut12.G71V cDNA and $\sim 300$ bp $3^{\prime}$ of the gene, which was cloned into Ndel-Smal-digested pREP81.

\section{Construction of GST-Cut12 fusion protein and antiserum} production

A full-length cut $12^{+}$with $\mathrm{N}$ del at $\mathrm{M} 33$ was digested with $\mathrm{N}$ del and Pvull and cloned into the plasmid pGEX4T-3. This construct was transformed into the Escherichia coli strain BRL21 for the expression of GST-Cut12 fusion protein. Bacterially produced protein was eluted from a polyacrylamide gel by electrophoresis at $100 \mathrm{~m} \AA$ and dialysed against phosphate buffered saline. One hundred fifty micrograms of the resulting insoluble suspension of protein was mixed with complete Freund's adjuvant for the first injection, and incomplete Freund's adjuvant for two subsequent boosts. Antisera and affinity-purified sera were produced as described in Harlow and Lane (1988). Western blot detection was carried out with peroxidase conjugated anti-rabbit secondary antibody.

\section{Fluorescence and immunofluorescence microscopy}

For immunofluorescence microscopy, the procedures described by Hagan and Hyams (1988) were followed. The affinity purified anti-Sad1 antibody AP9.2 (Hagan and Yanagida 1995), anti-tubulin antibody TAT 1 (Woods et al. 1989), and anti-Pk tag antibody 336 (Hanke et al. 1992) have been described previously. To improve microtubule preservation in cells double labeled with anti-tubulin and anti-Cut12, cells were mixed with an equal volume of prewarmed YES media plus $2.4 \mathrm{M}$ sorbitol for $5 \mathrm{~min}$ prior to fixation in $4 \%$ paraformal dehyde. For the observation of GFP-Cut12 protein, cells were cultured in YES media, washed once in phosphate-buffered saline, and dried onto coverslips. GFP fusions were observed by use of Zeiss FITC set 10.

\section{Electron microscopy}

For el ectron microscopic local ization of Cut12 and Pk antigens, samples were prepared by a modification of the methods of Ding et al. (1997). Briefly, cells were collected on a $0.45 \mu \mathrm{m}$ millipore filter by vacuum filtration and were frozen in a Balzer's high pressure freezer (Balzers, Lichtenstein). Frozen samples were freeze-substituted on $0.1 \%$ gluteral dehyde in acetone at $-90^{\circ} \mathrm{C}$, warmed to $-50^{\circ} \mathrm{C}$, and embedded in Lowicryl HM 20. Immunostaining was carried out as described previously (Demeter et al. 1995), by use of antibodies to Cut12 and Pk antigens followed by secondary antibodies conjugated to 10 and $5 \mathrm{~nm}$ of colloidal gold, respectively. Serial sections were imaged in a Philips CM 10 el ectron microscope, negatives were digitized, and computer models were generated using the IM OD software package (Kremer et al. 1996).

\section{Acknowledgments}

We thank Paul N urse for providing S. pombe strains, Keith Gull and Rick Randall for the TAT1 and 336 anti-Pk antibodies, respectively, and Tony Carr and Chris N orbury for providing the S. pombe genomic and CDN A libraries, respectively, and David $M$ astronardre for images of immunoel ectron microscopic localization of Cut12. We also thank Tony Carr, Paul Clarke, Dick Mclntosh, Paul Nurse, Viesturs Simanis, and Marc Sohrmann for stimulating discussions and critical reading of the manuscript. This work was supported by grants from the Cancer Research Campaign to I.H., N ational Institutes of Health grants GM 33787 and RR00592 in support of M.M., and a grant from the British Council to the UK Japan Cell Cycle Group to R.B. Imaging facilities in $\mathrm{M}$ anchester were al so supported by a grant from the Wellcome trust.

The publication costs of this article were defrayed in part by payment of page charges. This article must therefore be hereby marked "advertisement" in accordance with 18 USC section 1734 solely to indicate this fact.

\section{References}

Alfa, C.E., B. Ducommun, D. Beach, and J.S. Hyams. 1990. Distinct nuclear and spindle pole body populations of cyclincdc2 in fission yeast. Nature 347: 680-682.

Bailly, E., M. Doree, P. N urse, and M. Bornens. 1989. p34 ${ }^{\text {cdc2 }}$ is located both in nucleus and cytoplasm; part is centrosomally associated at G2/M and enters vesicles at anaphase. EMBO J. 8: 3985-3995.

Bailly, E., J. Pines, T. Hunter, and M. Bornens. 1992. Cytoplasmic accumulation of cyclin B1 in human cells: Association with a detergent resistant compartment and with the centrosome. J. Cell Sci. 101: 529-545.

Balczon, R. 1996. The centrosome in animal cells and its functional homologs in plant and yeast cells. Int. Rev. Cytol. 169: 25-82.

Barbet, N., W.J. M uriel, and A.M. Carr. 1992. Versatile shuttle vectors and genomic libraries for use with Schizosaccharomyces pombe. Gene 114: 59-66.

Basi, G., E. Schmid, and K. M aundrell. 1993. TATA box mutations in the Schizosaccharomyces pombe nmtl promoter affect transcription efficiency but not the transcription start point or thiamine repressibility. Gene 123: 131-136. 
Belmont, L.D., A.A. Hyman, K.E. Sawin, and T.J. Mitchison. 1990. Real time visualization of cell cycle dependent changes in microtubule dynamics in cytoplasmic extracts. Cell 62: 579-589.

Berry. L.D. and K.L. Gould. 1996. Novel alleles of cdc13 and cdc2 isolated as suppressors of mitotic catastrophe in Schizosaccharomyces pombe. Mol. Gen. Genet. 251: 635646.

Blangy, A., H.A. Lane, P. d'Herin, M. Harper, M. Kress, and E. $\mathrm{N}$ igg. 1995. Phosphorylation by $\mathrm{p} 34^{\mathrm{cdc} 2}$ regulates spindle association of human Eg5, a kinesin related motor essential for bipolar spindle formation in vivo. Cell 83: 1159-1169.

Broek, D., R. Bartlett, K. Crawford, and P. N urse. 1991. p34 ${ }^{\text {cdc2 }}$ is involved in establishing the dependence of $\mathrm{S}$ phase upon completion of the previous mitosis. Nature 349: 388-393.

Buendia, B., G. Draetta, and E. Karsenti. 1992. Regulation of the microtubule nucleating activity of centrosomes in Xenopus egg extracts: Role of cyclin A-associated protein kinase. J. Cell Biol. 116: 1431-1442.

Bueno, A. and P. Russell. 1993. Two fission yeast B-type cyclins Cig2 and $\mathrm{Cdc} 13$ have different functions in mitosis. Mol. Cell. Biol. 13: 2286-2297.

Carr, A.M., S.A. MacN eill, J. Hayles, and P. N urse. 1989. Molecular cloning and sequence analysis of mutant alleles of the fission yeast cdc2 kinase gene: Implications for cdc2 protein structure and function. Mol. \& Gen. Genet. 218: 41-49.

Coleman, T.R., Z. Tang, and W.G. Dunphy. 1993. Negative regulation of the weel protein kinase by direct action of the nim1/cdr1 mitotic inducer. Cell 72: 919-929.

Demeter, J., M. Morphew, and S. Sazer. 1995. A mutation in RCC 1-related protein pim1 results in nuclear envel ope fragmentation in fission yeast. Proc. Natl. Acad. Sci. 92: 14361440.

Den Haese, G.J., N. Wal worth, A.M. Carr, and K.L. Gould. 1995. The Weel protein kinase regulates T14 phosphorylation of fission yeast cdc2. Mol. Biol. Cell 6: 371-385.

Ding, R., K.L. McDonald, and J.R. Mclntosh. 1993. Three dimensional reconstruction and analysis of mitotic spindles from the yeast Schizosaccharomyces pombe. J. Cell Biol. 120: 141-151.

Ding, R., R.R. West, M. M orphew, B.R. Oakley, and J.R. Mclntosh. 1997. The spindle pole body of Schizosaccharomyces pombe enters and leaves the nuclear envelope as the cell cycle proceeds. Mol. Biol. Cell 8: 1461-1479.

Ducommun, B., G. Draetta, P. Young, and D. Beach. 1990. Fission yeast $\mathrm{Cdc} 25$ is a cell cycle regulated protein. Biochem. Biophys. Res. Comm. 167: 301-309.

Dunphy, W.G. and A. Kumagai. 1991. The Cdc25 protein contains an intrinsic phosphatase activity. Cell 67: 189-196.

Fantes, P. 1979. Epistatic gene interactions in the control of division in fission yeast. Nature 279: 428-430.

Featherstone, C. and P. Russell. 1991. Fission yeast p107weel mitotic inhibitor is a tyrosine/serine kinase. Nature 349: 808-811.

Gautier, J., M.J. Solomon, R.N. Booher, J.F. Bazan, and M.W. Kirschner. 1991. Cdc25 is a specific tyrosine phosphatase that directly activates p34 ${ }^{\text {cdc2 }}$. Cell 67: 197-211.

Glover, D.M., H. Ohkura, and A. Tavares. 1996. Polo kinase: The choreographer of the mitotic stage? J. Cell Biol. 135: 1681-1684.

Gould, K.L. and P. N urse. 1989. Tyrosine phosphorylation of the fission yeast $\mathrm{cdc}^{+}$protein kinase regulates entry into mitosis. Nature 342: 39-42.

Gould, K.L., S. Moreno, N.K. Tonks, and P. Nurse. 1990. Complementation of the mitotic activator, p80 $0^{\text {cdc25 }}$, by a human tyrosine phosphatase. Science 250: 1573-1576.
Gould, K. and A. Feoktistova. 1996. Characterization of novel mutations at the Schizosaccharomyces pombe cdc2 regulatory phosphorylation site, tyrosine 15. Mol. Biol. Cell 7: 1573-1586.

Hagan, I.M . and J.S. Hyams. 1988. The use of cell division cycle mutants to investigate the control of microtubule distribution in the fission yeast Schizosaccharomyces pombe. J. Cell Sci. 89: 343-357.

Hagan, I. and M. Yanagida. 1990. N ovel potential mitotic motor protein encoded by the cut $7^{+}$gene. Nature 347: 563-566.

- - . 1995. The product of the spindle formation gene sad $1^{+}$ associates with the fission yeast spindle pole body and is essential for viability. J. Cell Biol. 129: 1033-1047.

-_- . 1997. Evidence for cell cycle specific, spindle pole body mediated, nuclear positioning in the fissi on yeast Schizosaccharomyces pombe. J. Cell. Sci. 110: 1851-1866.

Hanke, T., P. Szawlowski, and R.E. Randall. 1992. Construction of solid matrix-antibody-antigen complexes containing simian immunodeficiency virus p27 using tag-specific monoclonal antibody and tag linked antigen. J. Gen. Virol. 73: 653660.

Harlow, E. and D. Lane. 1988. Antibodies: A laboratory manual. Cold Spring Harbor Laboratory, Cold Spring Harbor, NY.

Hayles, J., D. Fisher, A. Woollard, and P. N urse. 1994. Temporal order of $\mathrm{S}$ phase and mitosis in fission yeast is determined by the state of the $\mathrm{p} 34^{\mathrm{cdc}}-$ mitotic cyclin B complex. Cell 78: 813-822.

Hoffmann, I., P.R. Clarke, M.J. Marcote, E. Karsenti, and G. Draetta. 1993. Phosphorylation and activation of human cdc25-C by cdc2-cyclin $B$ and its involvement in the self amplification of MPF at mitosis. EMBO J. 12: 53-60.

Horio, T., S. Uzawa, M.K. Jung, B. Oakley, K. Tanaka, and M. Yanagida. 1991. The fission yeast gamma tubulin is essential for mitosis and is localized to microtubule organizing centres. J. Cell Sci. 99: 693-700.

Hudson, D. and P. Young. 1993. Sequence of the Schizosaccharomyces pombe gtp $1^{+}$gene and identification of a novel family of putative GTP binding proteins. Gene 125: 191-193.

Hudson, J.D., H. Feilotter, and P.G. Young. 1990. stf1; non-wee mutations epistatic to cdc25 in the fission yeast Schizosaccharomyces pombe. Genetics 126: 309-315.

Hudson, J.D., H. Feilotter, C. Lingner, R. Rowley, and P.G. Young. 1991. stf1: A new suppressor of the mitotic control gene cdc25 in Schizosaccharomyces pombe. Cold Spring Harbor Symp. Q uant. Biol. 56: 599-604.

Hyman, A.A. and E. Karsenti. 1996. Morphogenetic properties of microtubules and mitotic spindle assembly. Cell 84: 401410

Izumi, T. and J.L. Maller. 1993. Elimination of cdc2 phosphorylation sites in the cdc25 phosphatase blocks initiation of M-phase. Mol. Biol. Cell 4: 1337-1350.

- - - 1995. Phosphorylation and activation of the Xenopus cdc25 phosphatase in the absence of cdc2 and cdk2 kinase activity. Mol. Biol. Cell 6: 215-226.

Izumi, T., D.H. Walker, and J.L. M aller. 1992. Periodic changes in phosphorylation of the Xenopus cdc25 phosphatase regulate its activity. Mol. Biol. Cell 3: 927-939.

Kalt, A. and M. Schliwa. 1993. Molecular components of the centrosome. Trends Cell Biol. 3: 118-128.

Kirschner, M. and T. Mitchison. 1986. Beyond self assembly: From microtubules to morphogenesis. Cell 45: 329-342.

Kremer, J.R., D.N . M astronarde, and J.R. M clntosh. 1996. Computer visualization of three-dimensional image data using IMOD. J. Struct. Biol. 116: 71-76.

Kuang, J., C.L. Ashorn, M. Gonzalez-Kuyvenhoven, and J.E. 
Penkala. 1994. cdc25 is one of the M PM-2 antigens involved in the activation of maturation promoting factor. Mol. Biol. Cell 5: 135-145.

Kumagai, A. and W.G. Dunphy. 1991. The cdc25 protein controls tyrosine dephosphorylation of the cdc2 protein in a cell free system. Cell 64: 903-914.

- - . 1992. Regulation of the cdc25 protein during the cell cycle in Xenopus extracts. Cell 70: 139-150.

- - . 1996. Purification and molecular cloning of PIx1, a cdc25-regulatory kinase from Xenopus egg extracts. Science 273: 1377-1380.

Labib, K., R.A. Craven, K. Crawford, and P. N urse. 1995. Dominant mutants identify new roles of p34 ${ }^{\text {cdc2 }}$ in mitosis. EMBO J. 14: 2155-2165.

Lane, H.A. and E.A. Nigg. 1996. Antibody microinjection reveals an essential role for human polo like kinase 1 (PIk1) in the functional maturation of mitotic centrosomes. J. Cell Biol. 135: 1701-1713.

Lee, M.S., T. Enoch, and H. Piwnica-Worms. 1994. mik1 encodes a tyrosine kinase that phosphorylates p34 cdc2 on tyrosine 15. J. Biol. Chem. 269: 30530-30537.

Lundgren, K., N. Walworth, R. Booher, M. Dembski, M. Kirschner, and D. Beach. 1991. Mik1 and weel cooperate in the inhibitory tyrosine phosphorylation of cdc2. Cell 64: 11111122.

Lupas, A., M. v-Dyke, and J. Stock. 1991. Predicting coiled coils from protein sequences. Science 252: 1102-1164.

MacN eill, S.A. and P. N urse. 1993. Genetic analysis of human p34 ${ }^{\text {cdc2 }}$ function in fission yeast. Mol. \& Gen. Genet. 236: 415-426.

Mal donado-Codina, G. and D.M. Glover. 1992. Cyclins A and B associate with chromatin and the polar regions of spindles, respectively, and do not undergo complete degradation at anaphase in syncytial Drosophila embryos. J. Cell Biol. 116: 967-976.

M asuda, H., M. Sevik, and W.Z. Cande. 1992. In vitro microtubule nucleating activity of spindle pole bodies in fission yeast Schizosaccharomyces pombe: Cell cycle dependent activation in Xenopus cell free extracts. J. Cell Biol. 117: 10551066.

Maundrell, K. 1993. Thiamine repressible expression vectors pREP and pRIP for fission yeast. Gene 123: 127-130.

McGowan, C.H. and P. Russell. 1995. Cell cycle regulation of human WEE1. EMBO J. 14: 2166-2175.

Millar, J.B.A., G. Lenaers, and P. Russell. 1992. Pyp3 PTPase acts as a mitotic inducer in fission yeast. EMBO J. 11: 49334941.

Moreno, S., P. N urse, and P. Russell. 1990. Regulation of mitosis by cyclic accumulation of $\mathrm{p}^{\mathrm{cdc} 25}$ mitotic inducer. Nature 344: 549-552.

Moreno, S., A. Klar, and P. N urse. 1991. An introduction to the molecular genetic analysis in the fission yeast Schizosaccharomyces pombe. Methods Enzymol. 194: 795-823.

Mueller, P.R., T.R. Coleman, and W.G. Dunphy. 1995. Cell cycle regulation of Xenopus weel-likekinase. Mol. Biol. Cell 6: 119-134.

Nigg, E. 1993. Cellular substrates of p34 ${ }^{\mathrm{cdc} 2}$ and its companion cyclin dependent kinases. Trends Cell Biol. 3: 296-301.

Nurse, P. 1975. Genetic control of cell size at cell division in yeast. Nature 256: 547-551.

_-_. 1990. U niversal control mechanisms regulating onset of M-phase. Nature 344: 547-551.

Oakley, B.R. and N.R. Morris. 1983. A mutation in Aspergillus nidulans that blocks the transition from interphase to metaphase. J. Cell Biol. 96: 1155-1158.

Ohkura, H., I.M. Hagan, and D.M. Glover. 1995. The conserved
Schizosaccharomyces pombe kinase plo1, required to form a bi pol ar spindle, the actin ring, and septum, can drive septum formation in $\mathrm{G}_{1}$ and $\mathrm{G}_{2}$ cells. Genes \& Dev. 9: 1059-1073.

Ohta, K., N. Shiina, E. Okumura, S.I. Hisinaga, T. Kishimoto, S. Endo, Y. Gotoh, E. N ishida, and H. Sakai. 1993. Microtubule nucleating activity of centrosomes in cell free extracts from Xenopus eggs: Involvement of phosphorylation and accumulation of pericentriolar material. J. Cell Sci. 104: 125-137.

Osmani, A.H., S.L. M cGuire, and S.A. Osmani. 1991a. Parallel activation of the NIMA and $\mathrm{p} 34^{\mathrm{cdc} 2}$ cell cycle regulated protein kinases is required to initiate mitosis in $A$. nidulans. Cell 67: 283-291.

Osmani, A.H., K. O'Donnell, R.T. Pu, and S.A. Osmani. 1991b. Activation of the NIMA protein kinase plays a unique role during mitosis that cannot be bypassed by absence of the BIME checkpoint. EMBO J. 10: 2669-2679.

Parker, L.L., S.A. Walter, P.G. Young, and H. Piwnica-Worms. 1993. Phosphorylation and inactivation of the mitotic inhibitor weel by the nim1/cdr1 kinase. Nature 363: 736-738.

Pichova, A., S.D. Kohlwein, and M. Yamamoto. 1995. N ew arrays of cytoplasmic microtubules in the fission yeast Schizosaccharomyces pombe. Protoplasma 188: 252-262.

Pines, J. and T. Hunter. 1991. Human cyclins A and B1 are differentially located in the cell and undergo cell cycle dependent nuclear transport. J. Cell Biol. 115: 1-17.

Pockwinse, S.M ., G. Krockmal nic, S.J. Doxsey, J. N ickerson, J.B. Lian, A.J. van Wijen, J.L. Stein, G.S. Stein, and S. Penman. 1997. Cell cycle independent interaction of cdc2 with the centrosome, which is associated with the nuclear matrix intermediate filament scaffold. Proc. Natl. Acad. Sci. 94: 3022-3027.

Russell, P. and P. N urse. 1986. cdc $25^{+}$functions as an inducer in the mitotic control of fission yeast. Cell 45: 145-153.

-_- 1987a. N egative regulation of mitosis by weel $1^{+}$, a gene encoding a protein kinase homolog. Cell 49: 559-567.

_-_. 1987b. The mitotic inducer nim1 ${ }^{+}$functions in a regulatory network of protein kinase homologs controlling the initiation of mitosis. Cell 49: 569-576.

Saitoh, S., K. Takahashi, and M. Yanagida. 1997. Mis6, a fission yeast inner centromere protein, acts during $\mathrm{Gl} / \mathrm{S}$ and forms specialized chromatin required for equal segregation. Cell 90: 131-143.

Sambrook, J., E.F. Fritsch, and T. Maniatis. 1989. Molecular cloning: A laboratory manual 2nd ed. Cold Spring Harbor Laboratory Press, Cold Spring Harbor, NY.

Sohrmann, M., S. Schmidt, I. Hagan, and V. Simanis. 1998. Asymmetric segregation on spindle poles of the Schizosaccharomyces pombe septum inducing protein kinase C dc7p. Genes \& Dev. 12: 84-94.

Strausfeld, U., J.C. Labbe, D. Fesquet, J.C. Cavadore, A. Picard, K. Sadhu, P. Russell, and M. Doree. 1991. Dephosphorylation and activation of a p34 ${ }^{\mathrm{cdc}} / \mathrm{cyclin} \mathrm{B}$ complex in vitro by a human CDC25 protein. Nature 351: 242-245.

Tanaka, K. and T. Kanbe. 1986. Mitosis in the fission yeast Schizosaccharomyces pombe as reveal ed by freeze substitution electron microscopy. J. Cell Sci. 80: 253-268.

Tang, Z., T.R. Coleman, and W.G. Dunphy. 1993. Two distinct mechanisms for negative regulation of the weel protein $\mathrm{ki}$ nase. EMBO J. 12: 3427-3436.

Verde, F., J.C. Labbe, M. Doree, and E. Karsenti. 1990. Regulation of microtubule dynamics by cdc2 protein kinase in cell free extracts of Xenopus eggs. Nature 343: 233-238.

Verde, F., M. Dogterom, E. Stelzer, E. Karsenti, and S. Leibler. 1992. Control of microtubule dynamics and length by cyclin A and cyclin B dependent protein kinases in Xenopus egg extracts. J. Cell Biol. 118: 1097-1108. 
Bridge et al.

Watanabe, N., M. Broome, and T. Hunter. 1995. Regulation of the human WeelHu CDK tyrosine 15-kinase during the cell cycle. EMBO J. 14: 1878-1891.

Westendorf, J.M., P.N. Rao, and L. Gerace. 1994. Cloning of cDNAs for $M$ phase phosphoproteins recognized by the M PM 2 monoclonal antibody and determination of the phosphorylated epitope. Proc. Natl. Acad. Sci. 91: 714-718.

Woods, A., T. Sherwin, R. Sasse, T.H. MacRae, A.J. Baines, and K. Gull. 1989. Definition of individual components within the cytoskeleton of Trypanosoma brucei by a library of monoclonal antibodies. J. Cell Sci. 93: 491-500.

Wu, L. and P. Russell. 1993. Niml kinase promotes mitosis by inactivating Weel tyrosine kinase. Nature 363: 738-741.

Ye, X.S., G. Xu, P.T. Pu, R.R. Fincher, S.L. McGuire, A.H. Osmani, and S.A. Osmani. 1995. The NIM A protein kinase is hyperphosphorylated and activated downstream of p34 cdc2/ cyclin B: Coordination of two mitosis promoting kinases. EMBO J. 14: 986-994.

Ye, X.S., R.R. Fincher, A. Tang, K O'Donnell, and S.A. Osmani. 1996. Two S phase checkpoint systems, one involving the function of both BIME and Tyr15 phosphorylation of p34 ${ }^{\mathrm{cdc}}$ / cyclin B, inhibit NIMA and prevent premature mitosis. EMBO J. 15: 3599-3610. 


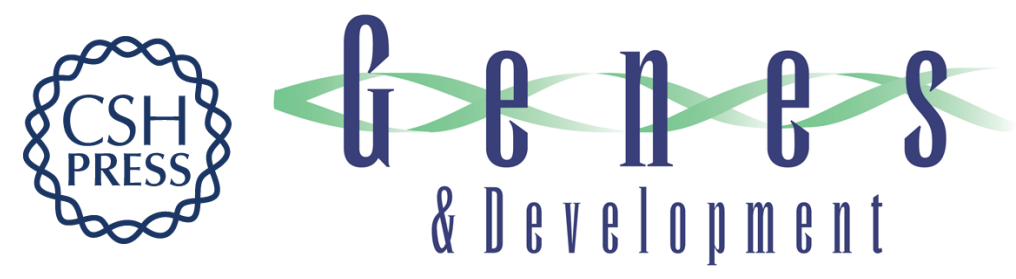

\section{The fission yeast SPB component Cut12 links bipolar spindle formation to mitotic control}

Alan J. Bridge, Mary Morphew, Rachel Bartlett, et al.

Genes Dev. 1998, 12:

References This article cites 89 articles, 36 of which can be accessed free at:

http://genesdev.cshlp.org/content/12/7/927.full.html\#ref-list-1

License

Email Alerting Receive free email alerts when new articles cite this article - sign up in the box at the top Service right corner of the article or click here.

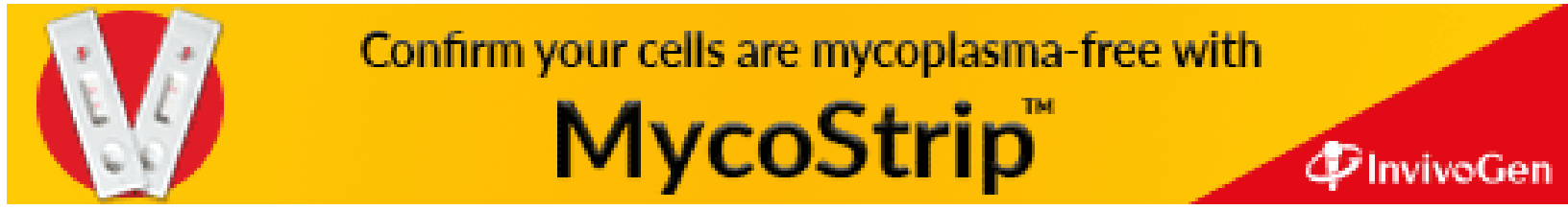

